\title{
Oceanic emissions of dimethyl sulfide and methanethiol and their contribution to sulfur dioxide production in the marine atmosphere
}

\author{
Gordon A. Novak ${ }^{1, a}$, Delaney B. Kilgour ${ }^{1}$, Christopher M. Jernigan ${ }^{1}$, Michael P. Vermeuel ${ }^{1, b}$, and \\ Timothy H. Bertram ${ }^{1}$ \\ $5 \quad{ }^{1}$ Department of Chemistry, University of Wisconsin - Madison, Madison, WI \\ ${ }^{a}$ Now at Cooperative Institute for Research in Environmental Sciences, University of Colorado Boulder, Boulder, CO 80309 \\ and NOAA Chemical Sciences Laboratory (CSL), Boulder, CO 80305 \\ ${ }^{\mathrm{b}}$ Now at Department of Soil, Water, and Climate, University of Minnesota - Twin Cities, St. Paul, MN, USA, 55108 \\ Correspondence to: Timothy H. Bertram (timothy.bertram@wisc.edu)
}

10 Abstract. Oceanic emissions of dimethyl sulfide $\left(\mathrm{CH}_{3} \mathrm{SCH}_{3}\right.$, DMS $)$ have long been recognized to impact aerosol particle composition and size, the concentration of cloud condensation nuclei $(\mathrm{CCN})$, and Earth's radiation balance. The impact of oceanic emissions of methanethiol $\left(\mathrm{CH}_{3} \mathrm{SH}, \mathrm{MeSH}\right)$, which is produced by the same oceanic precursor as DMS, on the volatile sulfur budget of the marine atmosphere is largely unconstrained. Here we present direct flux measurements of MeSH oceanic emissions using the eddy covariance (EC) method with a high-resolution proton-transfer-reaction time-of-flight mass

15 spectrometer (PTR-ToFMS) detector and compare them to simultaneous flux measurements of DMS emissions from a coastal ocean site. Campaign mean mixing ratios of DMS and MeSH were $72 \mathrm{ppt}$ (28-90 ppt interquartile range) and 19.1 ppt (7.6$24.5 \mathrm{ppt}$ interquartile range) respectively. Campaign mean (and interquartile range) emission fluxes of DMS $\left(F_{D M S}\right)$ and $\mathrm{MeSH}$ $\left(F_{\text {MeSH }}\right)$ were $1.13(0.53-1.61)$ and $0.21(0.10-0.31) \mathrm{ppt} \mathrm{m} \mathrm{s}^{-1}$ respectively. Linear least squares regression of observed MeSH and DMS flux indicates the emissions are highly correlated with each other $\left(\mathrm{R}^{2}=0.65\right)$ over the course of the campaign,

20 consistent with a shared oceanic source. The campaign mean DMS to MeSH flux ratio $\left(F_{D M S}: F_{M e S H}\right)$ was $5.5 \pm 3.0$ calculated from the ratio of 304 individual coincident measurements of $F_{D M S}$ and $F_{M e S H}$. Measured $F_{D M S}: F_{M e S H}$ was weakly correlated (R ${ }^{2}$ $=0.15$ ) with ocean chlorophyll concentrations, with $F_{D M S}: F_{M e S H}$ reaching a maximum of $10.8 \pm 4.4$ during a phytoplankton bloom period. No other volatile sulfur compounds were observed by PTR-ToFMS to have a resolvable emission flux above their flux limit of detection or to have a gas phase mixing ratio consistently above their limit of detection during the study

25 period, suggesting DMS and MeSH are the dominant volatile organic sulfur compounds emitted from the ocean at this site. The impact of this MeSH emission source on atmospheric budgets of sulfur dioxide $\left(\mathrm{SO}_{2}\right)$ was evaluated by implementing observed emissions into a coupled ocean-atmosphere chemical box model using a newly compiled MeSH oxidation mechanism. Model results suggest that MeSH emissions lead to afternoon instantaneous $\mathrm{SO}_{2}$ production of $2.5 \mathrm{ppt} \mathrm{hr}{ }^{-1}$, which accounts for $30 \%$ of the instantaneous $\mathrm{SO}_{2}$ production in the marine boundary layer at the mean measured $F_{D M S}$ and $F_{M e S H}$.

30 This contribution of $\mathrm{MeSH}$ to $\mathrm{SO}_{2}$ production is driven by a higher effective yield of $\mathrm{SO}_{2}$ from $\mathrm{MeSH}$ oxidation and the shorter oxidation lifetime of MeSH compared to DMS. This large additional source of marine $\mathrm{SO}_{2}$ has not been previously considered in global models of marine sulfur cycling. The field measurements and modeling results presented here demonstrate that MeSH 
is an important contributor to volatile sulfur budgets in the marine atmosphere, and must be measured along with DMS in order to constrain marine sulfur budgets. This large additional source of marine reduced sulfur from MeSH will contribute to particle formation and growth and $\mathrm{CCN}$ abundance in the marine atmosphere, with subsequent impacts on climate.

\section{Introduction}

Dimethyl sulfide $\left(\mathrm{CH}_{3} \mathrm{SCH}_{3}\right.$, DMS) emissions from the ocean are the most abundant source of reduced sulfur to the marine atmosphere (Andreae, 1990; Bates et al., 1987b, 1992; Carpenter et al., 2012). The role of DMS as a driver of cloud condensation nuclei $(\mathrm{CCN})$ production, which ultimately impacts Earth's radiative budget in the marine atmosphere, has been 40 studied extensively (Bates et al., 1987a; Carslaw et al., 2013; Charlson et al., 1987; Quinn and Bates, 2011). The oxidation of DMS in the atmosphere ultimately leads to the production of methane sulfonic acid $\left(\mathrm{CH}_{3} \mathrm{SO}_{3} \mathrm{H}, \mathrm{MSA}\right)$ and sulfur dioxide $\left(\mathrm{SO}_{2}\right)$ which can be further oxidized to sulfuric acid $\left(\mathrm{H}_{2} \mathrm{SO}_{4}\right)$, contributing to particle formation and growth (Clarke et al., 1998; Hoffmann et al., 2016; Schobesberger et al., 2013; Sipila et al., 2010). Direct observations and mechanistic understanding of the intermediate products in the oxidation of DMS are limited, leading to large variability in estimates of $\mathrm{SO}_{2}$ yields $(31-$

$4598 \%$ ), where $\mathrm{SO}_{2}$ is a precursor to sulfuric acid $\left(\mathrm{H}_{2} \mathrm{SO}_{4}\right)$ and non-sea salt sulfate aerosol (nss- $\mathrm{SO}_{4}^{2-}$ ) (Faloona, 2009; Hoffmann et al., 2016). Previous efforts to constrain the total budget of $\mathrm{SO}_{2}$ in the marine boundary layer (MBL) have required assigning a near $100 \%$ yield of $\mathrm{SO}_{2}$ from DMS oxidation (Faloona et al., 2009). A $100 \%$ yield of $\mathrm{SO}_{2}$ appears inconsistent with known production of MSA from DMS oxidation and with results from multiple laboratory studies (Faloona, 2009). The high yield of $\mathrm{SO}_{2}$ from DMS necessary for closure of the $\mathrm{SO}_{2}$ budget in that study prompted speculation on the existence of other unknown

50 marine sulfur species which could contribute to $\mathrm{SO}_{2}$ production (Gray et al., 2011). Existence of other marine contributors to $\mathrm{SO}_{2}$ production would serve to reduce the implied $\mathrm{SO}_{2}$ yield from DMS and would potentially bring that yield closer to the $40-80 \%$ range typically determined in laboratory and modeling studies (Gray et al., 2011). Implementation of oceanic MeSH emissions and oxidation to $\mathrm{SO}_{2}$ in chemical transport models would result in an increase in sulfuric acid production with subsequent impacts on new particle formation and growth and $\mathrm{CCN}$ abundance.

\section{1.1 DMS and MeSH oceanic production}

Both DMS and the volatile reduced sulfur molecule methanethiol $\left(\mathrm{CH}_{3} \mathrm{SH}, \mathrm{MeSH}\right)$ are produced in seawater from the same precursor metabolite, dimethylsulfoniopropionate (DMSP) (Kiene and Linn, 2000a). Bacterial cleavage of dissolved DMSP $\left(\mathrm{DMSP}_{\mathrm{d}}\right)$ primarily produces dissolved DMS $\left(\mathrm{DMS}_{\mathrm{d}}\right)$, and DMSP demethylation or demethiolation produces dissolved MeSH $\left(\mathrm{MeSH}_{\mathrm{d}}\right.$ ) (Yoch, 2002). $\mathrm{MeSH}_{\mathrm{d}}$ is the dominant product of $\mathrm{DMSP}_{\mathrm{d}}$ consumption with a total yield on the order of $75 \%$, 60 compared to an approximately $10 \%$ yield of $\mathrm{DMS}_{\mathrm{d}}$ (Kettle et al., 2001; Kiene and Linn, 2000b, 2000a). While yields of MeSH are higher compared to $\mathrm{DMS}_{\mathrm{d}}, \mathrm{MeSH}_{\mathrm{d}}$ is also more rapidly consumed by heterotrophic bacteria and phytoplankton, resulting in significantly faster turnover times (hours for $\mathrm{MeSH}_{\mathrm{d}}$, days for $\mathrm{DMS}_{\mathrm{d}}$ ) and lower steady state dissolved concentrations (Kiene, 1996). Both $\mathrm{MeSH}_{\mathrm{d}}$ and $\mathrm{DMS}_{\mathrm{d}}$ are persistently supersaturated in the dissolved phase resulting in ventilation to the atmosphere 
(Kettle et al., 2001; Lee and Brimblecombe, 2016). Surface ocean concentrations of $\mathrm{DMS}_{\mathrm{d}}$ have been measured extensively

65 and are on the order of 1-7 nM with higher values in the summer (Lana et al., 2011). This extensive collection of measurements has permitted the development of global climatologies of $\mathrm{DMS}_{\mathrm{d}}$ and emission fluxes for implementation into global chemical transport models (Galí et al., 2018; Lana et al., 2011). In contrast, measurements of $\mathrm{MeSH}_{\mathrm{d}}$ are sparse. Underway measurements from a transect of the Atlantic in September and October of 1998 showed a mean $\mathrm{MeSH}_{\mathrm{d}}$ of $0.39 \pm 0.34 \mathrm{nM}$ and a maximum of $1.7 \mathrm{nM}$ (Kettle et al., 2001). Mean $\mathrm{MeSH}_{\mathrm{d}}$ during that study was approximately $20 \%$ of $\mathrm{DMS}_{\mathrm{d}}$. In the Baltic

70 Sea, mean $\mathrm{MeSH}_{\mathrm{d}}$ was $0.16 \pm 0.12 \mathrm{nM}$ compared to $2.6 \pm 1.6 \mathrm{nM}$ for $\mathrm{DMS}_{\mathrm{d}}$ (Leck and Rodhe, 1991). MeSH emission fluxes were estimated to be $10 \%$ of DMS in that study. Significant variability in $\mathrm{DMS}_{\mathrm{d}}$ to $\mathrm{MeSH}_{\mathrm{d}}$ ratios were observed in those studies, emphasizing the need for more detailed study of the biogeochemical factors that control relative consumption and production of $\mathrm{DMS}_{\mathrm{d}}$ and $\mathrm{MeSH}_{\mathrm{d}}$.

\subsection{Atmospheric Fate of DMS}

75 Once emitted to the atmosphere, DMS is oxidized by hydroxyl $(\mathrm{OH})$, nitrate $\left(\mathrm{NO}_{3}\right)$, chlorine $(\mathrm{Cl})$, and bromine oxide $(\mathrm{BrO})$ radicals to produce lower volatility oxidized products which can contribute to aerosol particle formation and growth (Bates et al., 1987a; Charlson et al., 1987; Quinn and Bates, 2011). Gas phase mixing ratios of DMS in the MBL are typically on the order of 50-600 ppt, with higher concentrations generally associated with regions of high phytoplankton abundance, and with diel maxima at night when oxidative loss is at a minimum (Kettle et al., 2001; Kettle and Andreae, 2000; Kim et al., 2017;

80 Lana et al., 2011; Lawson et al., 2020; Sciare et al., 2000). Oxidation by OH, thought to be the largest loss pathway, proceeds either through $\mathrm{OH}$ addition or hydrogen abstraction. $\mathrm{OH}$ addition produces MSA, methane sulfinic acid (MSIA), dimethyl sulfoxide (DMSO), and $\mathrm{SO}_{2}$, while $\mathrm{H}$-abstraction is traditionally thought to primarily produce $\mathrm{SO}_{2}$ (Barnes et al., 2006; Conley et al., 2009; Hoffmann et al., 2016). The branching fraction of the $\mathrm{OH}$ oxidation channels is highly temperature dependent with $\mathrm{H}$-abstraction favored at higher temperatures ( $70 \%$ at $298 \mathrm{~K})$. The DMS H-abstraction product rapidly produces the 85 methylthiomethyl peroxy radical (MTMP, $\mathrm{CH}_{3} \mathrm{SCH}_{2} \mathrm{OO}$ ) following recombination with atmospheric oxygen. Until recently it was thought that MTMP primarily participates in further bimolecular reactions with the hydroperoxyl radical $\left(\mathrm{HO}_{2}\right)$, nitric oxide (NO), or other peroxy radicals $\left(\mathrm{RO}_{2}\right)$ which efficiently produce the methyl thiyl radical $\left(\mathrm{CH}_{3} \mathrm{~S} \cdot\right)$ and ultimately $\mathrm{SO}_{2}$ (Barnes et al., 2006; Hoffmann et al., 2016). Theoretical and laboratory studies have shown that MTMP can also undergo a series of intramolecular hydrogen shift rearrangements and additions of $\mathrm{O}_{2}$ to form the stable product hydroperoxymethyl

90 thioformate (HPMTF; $\mathrm{HOOCH}_{2} \mathrm{SCHO}$ ) at a rate that is competitive with bimolecular reactions (Berndt et al., 2019; Wu et al., 2015). HPMTF has been shown to be globally ubiquitous in the marine boundary layer from airborne observations (Veres et al., 2020) and at a coastal ocean ground site (Vermeuel et al., 2020). Global chemical transport modelling shows that $46 \%$ of emitted DMS goes on to form HPMTF (Novak et al., 2021). The atmospheric fate of HPMTF is an active topic of research but ambient observations show that dry deposition to the ocean surface is a significant loss term (lifetime $\sim 30$ hours, (Vermeuel 95 et al., 2020)) and that HPMTF is efficiently lost to clouds (Novak et al., 2021; Veres et al., 2020; Vermeuel et al., 2020), resulting in a $35 \%$ decrease in global $\mathrm{SO}_{2}$ production from DMS oxidation (Novak et al., 2021). These previously unconsidered 
loss processes for DMS derived sulfur may necessitate reevaluation of marine $\mathrm{SO}_{2}$ budgets (Bandy et al., 2011; Faloona et al., 2009).

\subsection{Atmospheric Fate of MeSH}

100 Comparatively little is known about the atmospheric abundance of MeSH. To date, only two ambient observations of MeSH atmospheric mixing ratios have been presented in the literature. Measurements in the remote south-west Pacific showed MeSH mixing ratios from $<10 \mathrm{ppt}$ to $65 \mathrm{ppt}$ which were 3-36\% of coincident DMS mixing ratios (Lawson et al., 2020). DMS and $\mathrm{MeSH}$ emission fluxes were inferred in that study from the rate of accumulation at night when oxidative loss was assumed to be zero, which showed that MeSH emission fluxes were $14-24 \%$ of the DMS flux. MeSH mixing ratios in the coastal and

105 inshore waters west of the Antarctic peninsula were up to $3.6 \mathrm{ppt}$, which was 3\% of coincident DMS (Berresheim, 1987). To our knowledge there have been no previous direct eddy covariance measurements of MeSH emission flux from the ocean.

While the bimolecular rate constants of $\mathrm{MeSH}$ with the primary atmospheric oxidants $\left(\mathrm{OH}, \mathrm{BrO}, \mathrm{NO}_{3}, \mathrm{Cl}\right)$ are known, there has been limited study on the reactive intermediates or yields of stable products from MeSH oxidation (Butkovskaya and Setser, 1999; Tyndall and Ravishankara, 1991). However, oxidation of MeSH by OH (R1) has been shown to produce the

110 methyl thiyl radical $\left(\mathrm{CH}_{3} \mathrm{~S} \cdot\right)$ at a yield of $1.1 \pm 0.2$ (Tyndall and Ravishankara, 1989), providing a mechanistic link to known reactions in the DMS H-abstraction pathway (R1) (Barnes et al., 2006). $\mathrm{CH}_{3} \mathrm{~S} \cdot$ production from DMS H-abstraction is the major pathway for $\mathrm{SO}_{2}$ production from DMS, and the reactions of $\mathrm{CH}_{3} \mathrm{~S} \cdot$ are therefore well studied (Barnes et al., 2006). Other studies have shown that the reaction of $\mathrm{MeSH}$ with $\mathrm{OH}$ occurs primarily at the $\mathrm{S}-\mathrm{H}$ group $(0.87 \pm 0.03)$ forming $\mathrm{CH}_{3} \mathrm{~S} \cdot$, with a minor channel of $\mathrm{H}$-abstraction from the methyl group $(0.13 \pm 0.03)$ (Butkovskaya and Setser, 2021). Recent ab 115 initio/RKKM calculations determined the $\mathrm{CH}_{3} \mathrm{~S} \cdot$ yield from $\mathrm{MeSH}+\mathrm{OH}$ at $298 \mathrm{~K}$ and 760 torr to be 0.98 (Mai et al., 2020). Given the slight inconsistency between the directly measured $\mathrm{CH}_{3} \mathrm{~S} \cdot$ yield of $1.1 \pm 0.2$ and the $\mathrm{MeSH}+\mathrm{OH}$ branching fractions, we take these experiments to provide an upper and lower bound on the $\mathrm{CH}_{3} \mathrm{~S} \cdot$ yield of 0.87 and 1.1 , and assume a $\mathrm{CH}_{3} \mathrm{~S} \cdot$ yield of 1 for R1 throughout this analysis.

$\mathrm{OH}+\mathrm{CH}_{3} \mathrm{SH} \rightarrow \mathrm{CH}_{3} \mathrm{~S}+\mathrm{H}_{2} \mathrm{O}$

$120 \mathrm{CH}_{3} \mathrm{~S}$ - efficiently produces $\mathrm{SO}_{2}$ through a series of competing reactions outlined in R2-R8 (Barnes et al., 2006; Hoffmann et al., 2016; Lucas, 2002; Mardyukov and Schreiner, 2018). As shown in $\mathrm{R} 2, \mathrm{CH}_{3} \mathrm{~S}$ - experiences reversible addition of $\mathrm{O}_{2}$ producing a methyl thiyl peroxy radical $\left(\mathrm{CH}_{3} \mathrm{SOO}\right)$ which can then undergo a series of unimolecular reactions $(\mathrm{R} 3-\mathrm{R} 4)$ to efficiently produce $\mathrm{SO}_{2}$.

$\mathrm{CH}_{3} \mathrm{~S}+\mathrm{O}_{2} \leftrightarrow \mathrm{CH}_{3} \mathrm{SOO}$

$\mathrm{CH}_{3} \mathrm{SOO} \rightarrow \mathrm{CH}_{3} \mathrm{~S}(\mathrm{O}) \mathrm{O}$

$\mathrm{CH}_{3} \mathrm{~S}(\mathrm{O}) \mathrm{O} \rightarrow \mathrm{SO}_{2}+\mathrm{CH}_{3}$

Bimolecular reactions of $\mathrm{CH}_{3} \mathrm{~S} \cdot$ with $\mathrm{O}_{3}$ and $\mathrm{NO}_{2}$ can also occur forming $\mathrm{CH}_{3} \mathrm{SO}$ (R5-R6). $\mathrm{CH}_{3} \mathrm{SO}$ primarily proceeds to react with $\mathrm{O}_{3}(\mathrm{R} 7)$ forming $\mathrm{CH}_{3} \mathrm{~S}(\mathrm{O}) \mathrm{O}$ which links back to the $\mathrm{SO}_{2}$ producing channel through $\mathrm{R} 4$.

$\mathrm{CH}_{3} \mathrm{~S}+\mathrm{O}_{3} \rightarrow \mathrm{CH}_{3} \mathrm{SO}+\mathrm{O}_{2}$ 
A minor $\left(\sim 1 \%\right.$ at open ocean $\mathrm{O}_{3}$ mix can also occur to produce $\mathrm{CH}_{3} \mathrm{SO}_{3}$ which can react further to produce $\mathrm{SO}_{3}$ and MSA (Barnes et al., 2006).

$\mathrm{CH}_{3} \mathrm{~S}(\mathrm{O}) \mathrm{O}+\mathrm{O}_{3} \rightarrow \mathrm{CH}_{3} \mathrm{SO}_{3}$

135 The atmospheric yield of $\mathrm{SO}_{2}$ from the oxidation of MeSH by $\mathrm{OH}$ under low $\mathrm{NO}_{\mathrm{x}}$ was recently reported as 0.98 based on modeling results constrained by a laboratory oxidation study, which is in good agreement with the efficient production of $\mathrm{SO}_{2}$ from MeSH proposed in our reaction scheme (Chen et al., 2021). We exploit this link between MeSH oxidation by OH and known DMS oxidation chemistry to develop a MeSH oxidation mechanism for implementation into a 0-D chemical box model as described further in the subsequent text. The full set of reactions with rate equations are provided in Table S1.

140 Here we present eddy covariance (EC) flux measurements of DMS and MeSH emissions at a coastal ocean site using a high sensitivity Vocus PTR-TOF for detection (Krechmer et al., 2018). Results from this study show that emission fluxes of DMS $\left(F_{D M S}\right)$ and $\mathrm{MeSH}\left(F_{M e S H}\right)$ were well correlated $\left(\mathrm{R}^{2}=0.65\right)$ and that $F_{M e S H}$ is a significant contributor to marine sulfur emissions

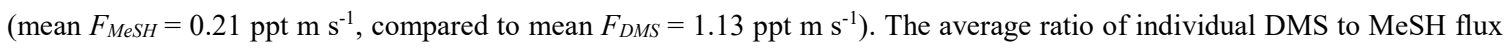
$\left(F_{D M S}: F_{M e S H}\right)$ measurements for the full campaign was $5.5 \pm 3.0$. We assess the impact of the observed large MeSH emission

145 flux on production of $\mathrm{SO}_{2}$ in the marine atmosphere through a coupled ocean flux -atmospheric chemistry 0-D box model with a newly compiled MeSH oxidation mechanism. Modeling results suggest that MeSH contributes approximately 30\% of instantaneous afternoon $\mathrm{SO}_{2}$ production $\left(\mathrm{P}_{\mathrm{SO} 2}\right)$. Together these results show that $\mathrm{MeSH}$ emissions are an important contributor to sulfur budgets in the marine atmosphere and further field studies and laboratory oxidation mechanism investigations are warranted.

\section{Experimental Methods}

\subsection{Scripps Pier Flux Experiment Overview}

Measurements of DMS and MeSH gas phase mixing ratios and EC flux were made continuously from the end of the Ellen Browning Scripps Memorial Pier (hereon SIO Pier) at the Scripps Institution of Oceanography in La Jolla, CA, USA during September 2019. The SIO Pier is $330 \mathrm{~m}$ long and extends over $100 \mathrm{~m}$ beyond the wave breaking zone. The SIO Pier site has

155 been used regularly for EC studies of ocean-atmosphere trace gas exchange (Kim et al., 2014; Novak et al., 2020; Porter et al., 2018; Vermeuel et al., 2020). The SIO Pier experiences a characteristic sea-breeze circulation pattern during summer where winds are from the ocean at moderate windspeeds $\left(0-6 \mathrm{~m} \mathrm{~s}^{-1}\right)$ during daytime and are from land at night, which limits nighttime flux determinations. DMS and MeSH were detected with a latest generation Vocus PTR-TOF (Vocus) instrument (TOFWERK, Aerodyne), with an HTOF mass analyzer (resolution $c a 5000 \mathrm{~m} / \Delta \mathrm{m}$ for DMS and MeSH) (Krechmer et al.,

160 2018). The Vocus was housed in a temperature-controlled trailer at the end of the pier and sampled through a $19 \mathrm{~m}$ long PFA inlet $(0.625 \mathrm{~cm}$ i.d.) enclosed in an opaque housing to prevent photochemistry in the sampling line. The inlet was pumped at 
22 slpm which maintained turbulent flow and short residence times in the sampling line (Reynolds number 4280, calculated volumetric evacuation time $1.7 \mathrm{~s}$ ). The full inlet line was held at $40^{\circ} \mathrm{C}$ which was always above ambient temperatures to prevent condensation of water vapor on inlet surfaces. A bypass line through the Vocus front end subsampled from the main inlet at 5 slpm through a PFA tee located at the instrument interface. The Vocus subsampled from this bypass at a flow rate of $100 \mathrm{sccm}$ immediately in front of the Vocus capillary inlet into the instrument drift tube. This sampling configuration was used to reduce residence times in the sampling lines as much as possible (total estimated inlet and instrument residence time $\sim 1.9 \mathrm{~s}$ ). In addition to the main inlet line, all surfaces in contact with the ambient sample flow, including unions and valves, were composed of PFA or PEEK in order to minimize known surface artifacts for MeSH sampling except for one stainless-steel union at the Vocus subsampling point (Perraud et al., 2016). The ambient inlet sampling point was collocated with a sonic anemometer recording three-dimensional winds at $10 \mathrm{~Hz}$ (Gil HS-50). The sonic anemometer and Vocus inlet were mounted on a $6.1 \mathrm{~m}$ long boom extended beyond the end of the pier to minimize flow distortions from the pier. The inlet was mounted on the boom at a height of $13 \mathrm{~m}$ above the mean lower low tide level. Ocean depth below the pier sampling point was $c a .6 \mathrm{~m}$. The Vocus was operated at a drift tube pressure of 1.5 mbar and an axial electric field gradient of $41.5 \mathrm{~V} \mathrm{~cm}^{-1}$ resulting in a

175 high overall effective field strength $(\mathrm{E} / \mathrm{N})$ of $143 \mathrm{Td}$. Mass spectra were recorded at $10 \mathrm{~Hz}$ for the full mass range of 19-500 $\mathrm{m} / \mathrm{Q}$. The second RF-only focusing quadrupole in the instrument was operated at an amplitude of $275 \mathrm{~V}$ at the start of the campaign before being reduced to 235 and ultimately $215 \mathrm{~V}$ later in the deployment. The reduced amplitude on the quadrupole increased transmission of low mass $(<50 \mathrm{~m} / Q)$ ions as described by Krechmer et al., (2018). MeSH (m/Q 49) transmission was increased by $10 \%$ at the reduced amplitude of $215 \mathrm{~V}$, compared to $275 \mathrm{~V}$, which was accounted for in the data processing.

180 Transmission efficiency of DMS was independent of the quadrupole amplitude as its nominal mass $(\mathrm{m} / Q 63)$ is larger than the mass discrimination window of the quadrupole. High resolution peak fitting and integration of the mass spectra was performed in the Tofware 3.2.0 software developed by the instrument manufacturer (TOFWERK).

Additional ancillary measurements made continuously from the pier included $\mathrm{O}_{3}$ mixing ratios, temperature, relative humidity, and incoming solar irradiance. $\mathrm{O}_{3}$ mixing ratios were measured at 1-minute time resolution (POM, 2B Technologies) in line

185 with the Vocus with a subsampling point immediately downstream of the Vocus subsampling point. Temperature and RH (Vaisala HMP110) were also measured inline downstream of the Vocus subsampling point at $1 \mathrm{~Hz}$ time resolution. Incoming total solar irradiance at $1 \mathrm{~Hz}$ time resolution (Licor LI-200R) was measured via a sensor mounted on top of the trailer housing the Vocus. Measurements of sea-surface temperature (SST), salinity, and chlorophyll are continuously collected at a 1-minute time resolution from the end of the pier from an automated shore station operated by the Southern California Coastal Ocean

\subsection{DMS and MeSH calibrations and limit of detections}

Instrument calibration factors for DMS were determined during ambient sampling by a two-point standard addition of a DMS gas standard (Praxair, $5.08 \mathrm{ppm} \pm 5 \%$ ) to the full sampling inlet every 2.5 to 4 hours. Campaign mean sensitivity to DMS was $3.9 \mathrm{cps} \mathrm{ppt}^{-1}$. Sensitivity to DMS was independent of RH. MeSH was not directly calibrated for during field sampling. Post 
195 campaign calibrations for MeSH were performed in the laboratory using a MeSH compressed gas standard (Airgas, $6.11 \pm 5 \%$ ppm) yielding a calibration factor of $1.3 \mathrm{cps} \mathrm{ppt}^{-1}$ for dry conditions. MeSH sensitivity was slightly humidity dependent resulting in the sensitivity at $80 \% \mathrm{RH}$ being $11 \%$ lower than at $0 \% \mathrm{RH}$. Calibrations for MeSH were performed with the same $19 \mathrm{~m}$ sampling line and flow conditions used for ambient sampling. We expect that this reduced sensitivity for MeSH at high $\mathrm{RH}$ is at least partially due to reactions on inlet surfaces which is a known complication in MeSH sampling (Perraud et al.,

200 2016). Ambient MeSH calibration factors were determined by scaling the measured in-field DMS calibration factors by the RH dependent DMS:MeSH sensitivity ratio determined from the laboratory calibrations. We note that the observed sensitivity ratio of DMS:MeSH is different from what would be predicted based on measured proton transfer rate coefficients which are approximately equal for DMS and MeSH (Williams et al., 1998), emphasizing the need for direct calibration of MeSH.

Instrument backgrounds were determined by overflowing the full inlet line with dry UHP $\mathrm{N}_{2}$ at the tip of the ambient sampling

205 point. Ambient sampling periods were subdivided into 30-minute blocks and were matched to the nearest temporal calibration and background determination point. The campaign mean, median, and interquartile range for DMS were 72.6, 49.2, and 28.089.8 ppt respectively. MeSH mean, median, and interquartile ranges mixing ratios were 19.1, 13.4, and 7.6-24.5 ppt. Limits of detection (LOD) at a signal-to-noise $(\mathrm{S} / \mathrm{N})$ ratio of three were $2.6 \mathrm{ppt}$ for DMS and $3.6 \mathrm{ppt}$ for MeSH for a $10 \mathrm{~s}$ averaging time following the calculation method of Bertram et al., (2011).

\section{$210 \quad 2.3$ Eddy Covariance Flux Measurements}

\subsubsection{Eddy Covariance Calculation Overview}

The flux $(F)$ of trace gas across the interface is described by Eq. 1, as a function of both the gas-phase $\left(C_{g}\right)$ and liquid phase $\left(C_{l}\right)$ concentrations and the dimensionless gas over liquid Henry's law constant $(H)$, where $K_{t}$, the total transfer velocity for the gas, encompasses all of the chemical and physical processes that govern air-sea gas exchange (Liss and Slater, 1974).

$215 F=K_{t}\left(H C_{l}-C_{g}\right)$

Both DMS and MeSH are persistently supersaturated in the liquid phase leading to an emission flux to the atmosphere (where a positive flux value indicates emission). Fluxes of DMS and MeSH were measured in the turbulent planetary boundary layer with the well-established eddy covariance (EC) technique, where $F$ is calculated as the time average of the instantaneous covariances from the mean of vertical wind $(w)$ and the scalar magnitude (x, here either DMS or MeSH) as shown in Eq. 2.

220 Overbars are means and primes are the instantaneous variance from the mean. $N$ is the total number data points during the flux averaging period. Ambient data was subdivided into approximately 30-minute flux averaging periods for the EC flux calculation.

$F_{x}=\frac{1}{N} \sum_{i=1}^{N}\left(w_{i}-\bar{w}\right)\left(x_{i}-\bar{x}\right)=\left\langle w^{\prime} x^{\prime}\right\rangle$ 


\subsubsection{EC Flux Data Processing and Quality Control}

225 Several standard EC data processing steps, data filters, and quality control checks were applied during flux analysis including: 1) filtering by wind direction for periods of onshore winds (true wind direction $200-360^{\circ}$ ), 2) coordinate rotation of threedimensional wind components by the planar fit method to remove unintentional tilts in the sonic mounting and account for local flow distortions (Wilczak et al., 2001), 3) application of a friction velocity $\left(U_{*}\right)$ threshold of $0.05 \mathrm{~cm} \mathrm{~s}^{-1}$ to reject periods of low shear driven turbulence, 4) despiking of DMS and MeSH data using a mean absolute deviation filter before the EC flux calculation (Mauder et al., 2013), 5) linear detrending of the scalar timeseries, and 6) flux stationarity filtering with flux periods rejected if they were non-stationary at a 30\% threshold (Foken and Wichura, 1996). Additional discussion of EC flux processing and quality control steps including lag time determination, spectral analysis, frequency attenuation corrections, and flux LOD determination are provided in SI. A total of 304 out of 696 flux measurment periods passed all quality control filters.

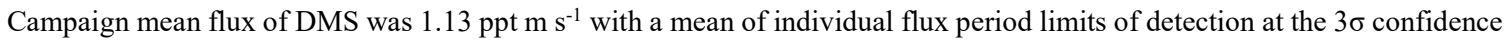
interval of $0.35 \mathrm{ppt} \mathrm{m} \mathrm{s}^{-1}$. MeSH mean flux was $0.21 \mathrm{ppt} \mathrm{m} \mathrm{s}^{-1}$ with a mean flux $3 \sigma$ LOD of $0.11 \mathrm{ppt} \mathrm{m} \mathrm{s}^{-1}$.

\subsection{Coupled ocean-atmosphere flux chemical box model}

\subsubsection{Meteorological and Chemical Constraints}

A coupled ocean-atmosphere 0-D chemical box model was developed using the Master Chemical Mechanism (MCM) v3.3.1 (http://mcm.york.ac.uk, Jenkin et al., 1997; Saunders et al., 2003) in the Framework for 0-D Atmospheric Modeling (F0AM,

240 Wolfe et al., 2016) with added chlorine chemistry (Riedel et al., 2014). The model was used to assess the impact of observed $\mathrm{MeSH}$ emissions on production of secondary marine $\mathrm{SO}_{2}$. Model ability to reproduce observed diel profiles of DMS and MeSH mixing ratios was also tested. Measured emission fluxes of MeSH and DMS are coupled into the model to set the source term for those molecules. Meteorological inputs were acquired from the NOAA National Data Buoy Center (Stations LJPC1 and LJAC1) as well as from an onsite temperature and relative humidity data logger (OM-62, Omega Engineering). Chemical

245 constraints included coincident measurements of $\mathrm{O}_{3}$ and nitryl chloride $\left(\mathrm{ClNO}_{2}\right)$ measured at the same site in August 2018 (Vermeuel et al., 2020), an assumed $\mathrm{OH}$ profile that followed the solar cycle with a peak at $4.0 \times 10^{6}$ molecules $\mathrm{cm}^{-3}$, and constant concentrations of other major trace gases as listed in Table S2. A constant first-order dilution loss term was used with a one-day lifetime to approximate mixing out of the boundary layer. A static boundary layer height (BLH) of $500 \mathrm{~m}$ was assumed (Faloona et al., 2005; Stull, 1988; Wei et al., 2018). Clear sky conditions were also assumed (i.e. no heterogeneous loss from reactive uptake on cloud droplets (Vermeuel et al., 2020)). An updated oxidation mechanism for DMS and MeSH was implemented, expanding upon the default DMS oxidation scheme in the MCM v3.3.1 to include oxidation of MeSH to form $\mathrm{CH}_{3} \mathrm{~S} \cdot(\mathrm{R} 1)$ and to include HPMTF chemistry, detailed in Table S1. The model was allowed to spin up for two days to allow reactive intermediates to reach equilibrium, with all reported values taken from day three of the model run. 


\subsubsection{Box Model Conditions}

\section{2.4.2.1 Pier Model Case}

Two distinct model cases were developed which differ in how they treat the diel profile of $F_{D M S}$ and $F_{M e S H}$. The first (termed the Pier Model Case) used the observed diel profile of $F_{D M S}$ and $F_{M e S H}$ at Scripps Pier to test model ability to reproduce observed diel profile of DMS and MeSH gas phase mixing ratios. Nighttime flux measurements from 23:00 to 09:00 were limited during this study due to persistent off-shore wind conditions. Instead, we apply a constant nighttime emission flux taken as the average

260 of the 9:00-10:00 and 21:00-22:00 flux observations for DMS and MeSH. A three-hour moving mean was also applied to the observed diel flux profiles to reduce the influence of experimental variability on the model. This Pier Model Case is used in the analysis of diel profiles presented in Section 3.4.

\subsubsection{Open Ocean Case}

A second case (termed Open Ocean Model Case) was developed to provide a general assessment of the relative contribution

265 of DMS and MeSH emissions to $\mathrm{SO}_{2}$ production as described in Section 3.5. This Open Ocean case uses fixed values for $F_{D M S}$ and $F_{M e S H}$ taken as the campaign mean fluxes, rather than a variable diel profile. This case avoids the ambiguity of uncertain nighttime emission flux in the observations and better represents conditions on the open ocean where there is little diel variability in wind speed and thus emission fluxes for DMS and MeSH are expected to be relatively constant (Archer and Jacobson, 2005). 

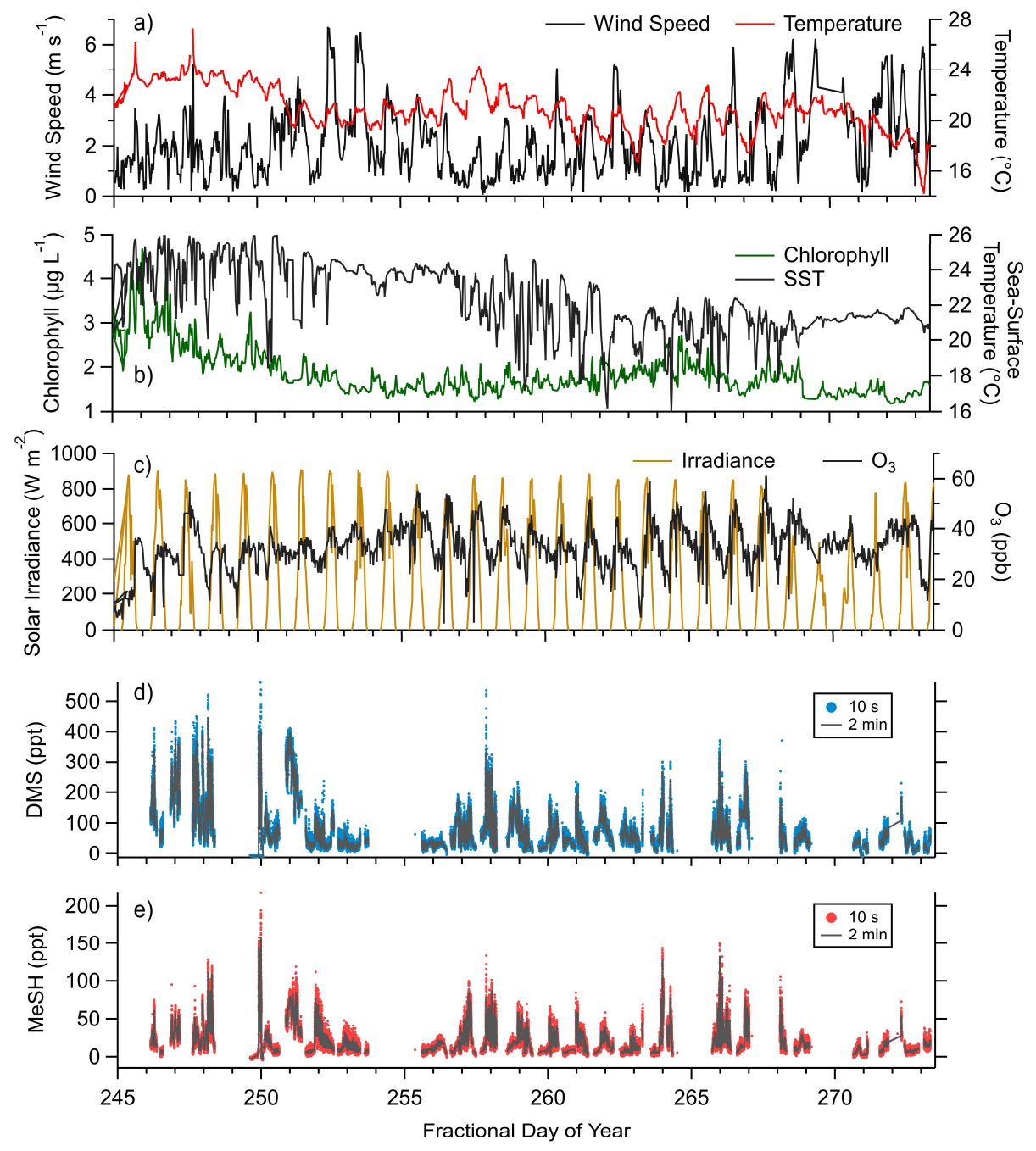

Figure 1. Campaign time series of (a) Wind speed and near surface air temperature, (b) chlorophyll concentration and sea-surface temperatures (SST), (c) Incoming solar irradiance (from $400-100 \mathrm{~nm}$ ) and ozone $\left(\mathrm{O}_{3}\right)$ mixing ratios, (d) mixing ratios of DMS at 10 $\mathrm{s}$ and 2 minute time resolution, and (e) mixing ratios of $\mathrm{MeSH}$ at $10 \mathrm{~s}$ and 2 minute time resolution.

\subsection{Meteorology Overview}

Observed meteorology and ocean physical and biogeochemical parameters showed minimal variance over the sampling period. Mean sea-surface temperature during the campaign was $23.3^{\circ} \mathrm{C}\left(21.6\right.$ to $24.7^{\circ} \mathrm{C}$ interquartile range). Observed mean and 
interquartile ranges of air temperatures and relative humidity were $22^{\circ} \mathrm{C}\left(19.5\right.$ to $\left.23.6^{\circ} \mathrm{C}\right)$ and $79.9 \%(72.3$ to $88.3 \%)$ respectively. Chlorophyll concentrations suggest moderate biological productivity with an observed campaign mean of 1.86

$\mu \mathrm{g} \mathrm{L} \mathrm{L}^{-1}$ (1.5 to $2.0 \mu \mathrm{g} \mathrm{L}^{-1}$ interquartile range). $\mathrm{O}_{3}$ mixing ratios showed a clear diel pattern peaking in mid-afternoon with a campaign mean of $32.6 \mathrm{ppbv}$ (27.6 to $38.9 \mathrm{ppbv}$ interquartile range). Wind speeds during onshore wind periods were from 0 to $6 \mathrm{~m} \mathrm{~s}^{-1}$, typically peaking in late afternoon with a campaign mean of $2.8 \mathrm{~m} \mathrm{~s}^{-1}$. Clear sky conditions were observed for most afternoons during the study period, with total solar irradiance peaking near noon. The period from day of year (DOY) 268-271 saw occasional overcast skies during the afternoon. Light rainfall during the early morning of the DOY 271 was the only

285 precipitation during the campaign. Morning and late evening periods showed occasional presence of marine stratocumulus clouds which drove day-to-day variability in solar irradiance during those times. The campaign timeseries of wind speed, air temperature, sea surface temperature (SST), $\mathrm{O}_{3}$ mixing ratios, solar irradiance, and DMS and MeSH mixing ratios are presented in Fig. 1. Gaps in the DMS and MeSH timeseries are from instrument maintenance periods, power outages at the site, and periods where the instrument was operated in an alternative sampling mode.

\section{3.2 DMS and MeSH Gas Phase Mixing Ratios}

The campaign mean, median, and interquartile range of DMS mixing ratios were 72.6, 49.2, and 28.0-89.8 ppt respectively. MeSH mean, median, and interquartile range mixing ratios were 19.1, 13.4, and 7.6-24.5 ppt. Maximum concentrations of DMS and MeSH during the campaign were 562 and $217 \mathrm{ppt}$ respectively, for $10 \mathrm{~s}$ time averaged data. The correlation of observed DMS and MeSH mixing ratios at 2 minute averaging time colored by the hour of day (local time, UTC-7) of the observation are shown in Fig. 2. The slope of the correlation was 0.19 with a linear least squares regression coefficient $\left(\mathrm{R}^{2}\right)$ of 0.61. The ratio of DMS:MeSH mixing ratios reaches a minimum near hours 05-07 following the buildup of MeSH overnight. Both DMS and MeSH were observed to reach a maximum in concentration at night, and minimum concentrations in the early afternoon as shown in the diel profiles in Fig. 3. The observed diel profile is consistent with expectations due to the significantly lower oxidative loss rate at night and has been observed in other studies (Lawson et al., 2020). MeSH varies by approximately

300 a factor of five between its diel average maximum and minimum concentration, compared to DMS which varies by approximately less than a factor of three. The larger diel variability in MeSH is due to its approximately five times faster bimolecular rate constant with $\mathrm{OH}\left(k_{O H+M e S H}=3.3 \times 10^{-11} \mathrm{~cm}^{3}\right.$ molecule $\mathrm{e}^{-1} \mathrm{~s}^{-1}$ at $\left.293 \mathrm{~K}\right)$ compared to DMS $\left(k_{O H+D M S}=7.8 \times 10^{-}\right.$ ${ }^{12} \mathrm{~cm}^{3}$ molecule $\mathrm{e}^{-1} \mathrm{~s}^{-1}$ at $293 \mathrm{~K}$ ) resulting in a lifetime of MeSH to oxidation by $\mathrm{OH}$ during the afternoon on the order of 3 hours compared to 16 hours for DMS (for $[\mathrm{OH}]=2 \times 10^{6}$ molecule $\mathrm{cm}^{-3}$ ). In the remote south-west Pacific Ocean, Lawson et al.

305 (2020) measured mean DMS and MeSH mixing ratios of 208 and 18 ppt respectively, with maximum concentrations observed at night. They also found that DMS and MeSH were correlated, with a slope of 0.07 and an $\mathrm{R}^{2}$ of 0.3 over the full campaign. We observe similar mean MeSH (19.1 ppt), lower DMS (72.6 ppt), and a larger slope for the correlation of DMS and MeSH (slope $=0.19$ ) in this study compared to the Lawson et al. (2020) observations. Still our results show general qualitative agreement with Lawson et al (2020), with both showing that atmospheric MeSH is present at a significant ratio relative to DMS. 


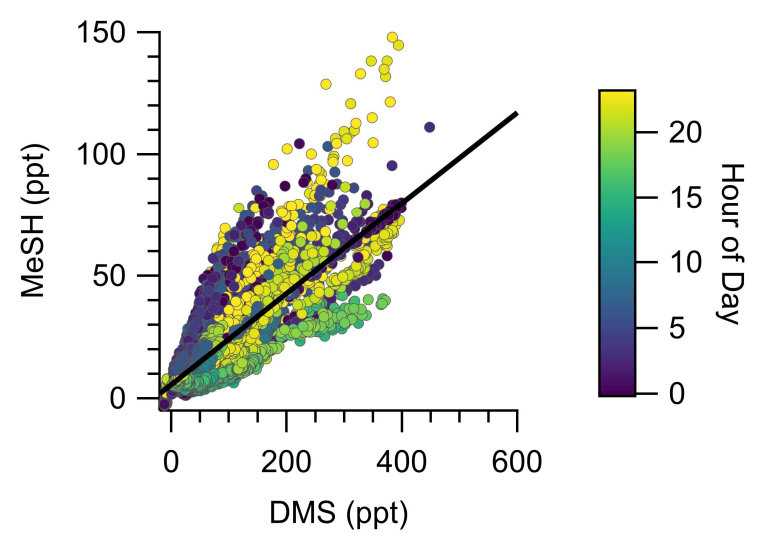

Figure 2. Correlation of DMS and MeSH mixing ratios at a 2 minute averaging time colored by hour of day of the observation. Hour of day is in local time (UTC -7). The linear least-squares best fit is plotted as the solid black line. The slope of the best fit line is 0.19 and $\mathbf{R}^{2}=\mathbf{0 . 6 1}$.
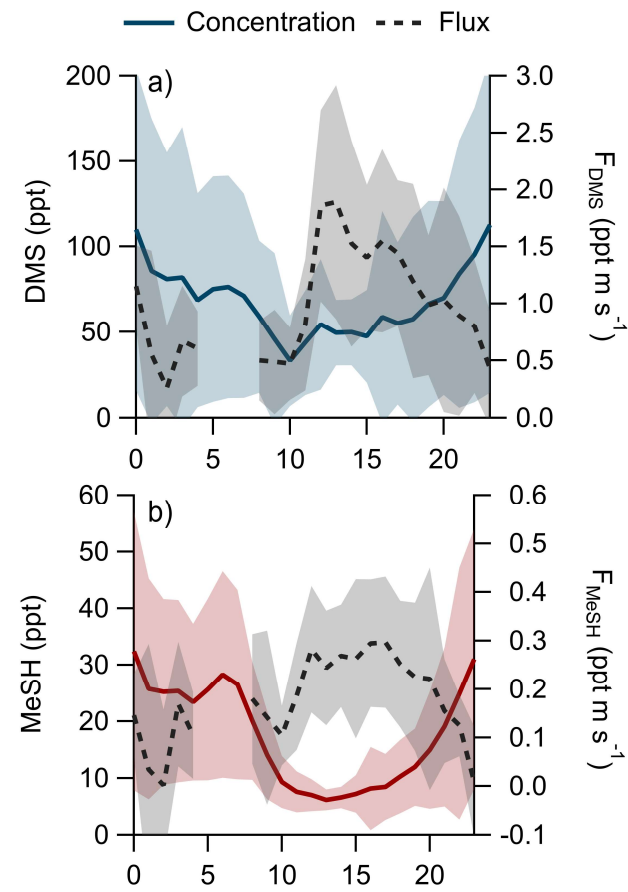

Hour of Day (Local Time, UTC -7)

Figure 3. Hourly averaged diel profiles of observed mixing ratios and eddy covariance flux of (a) DMS and (b) MeSH. Shading represents the standard deviation of the binned hourly means. Winds were primarily from the land for hours 0 to 10 , limiting airsea flux measurement during those times. 


\subsection{DMS and MeSH Emission Flux}

320 A total of 304 valid quality-controlled flux averaging periods were measured during the campaign. Campaign mean emission

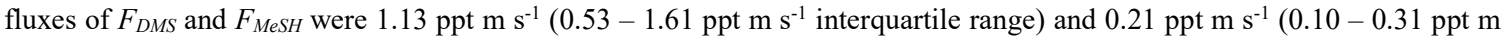
$\mathrm{s}^{-1}$ interquartile range) respectively. Both $F_{D M S}$ and $F_{M e S H}$ reached a steady maximum between hour of day 10 to 17 as shown in Fig. 3 which corresponds to the typical period of sustained peak wind speed. The magnitude of both $F_{D M S}$ and $F_{M e S H}$ were found to increase with wind-speed as shown in Fig 4, following expectations for supersaturated species at moderate wind speeds where flux magnitude is controlled by physical transfer terms (Carpenter et al., 2012; Huebert et al., 2004; Kim et al., 2017; Marandino et al., 2007). Measurement of $F_{D M S}$ and $F_{M e S H}$ during nighttime was limited due to persistent winds from the land at night throughout the campaign. Less than $15 \%$ of the valid flux observations were between the hours $22-07$. Further, those nighttime flux measurements were smaller and showed high variability compared to daytime measurements. DMS and MeSH fluxes were highly correlated with each other $\left(\mathrm{R}^{2}=0.65\right)$ as shown in Fig. 5a. Campaign mean $F_{D M S}: F_{M e S H}$ calculated

330 as the simple mean of the ratio of individual $F_{D M S}$ and $F_{M e S H}$ observations was $5.5 \pm 3.0$. Lawson et al. (2020) calculated the average emission flux of MeSH compared to DMS $\left(F_{M e S H} /\left(F_{M e S H}+F_{D M S}\right)\right)$ to be between $14 \%-24 \%$, where fluxes were calculated from the nighttime accumulation of DMS and MeSH when oxidative loss was assumed to be negligible. In this study using direct eddy covariance flux measurements, we calculate the mean $F_{M e S H} /\left(F_{M e S H}+F_{D M S}\right)$ to be $16 \%$, which compares well to the Lawson et al. (2020) result. As shown in Fig. 5b. $F_{D M S}: F_{M e S H}$ is partially correlated $\left(\mathrm{R}^{2}=0.15\right)$ with

335 ocean chlorophyll concentrations. The timeseries of chlorophyll concentrations shown in Fig. 1b. shows that chlorophyll peaked at the immediate start of gas phase sampling from DOY 245-246 at $c a .3 .5$ to $4 \mu \mathrm{g} \mathrm{L}^{-1}$ before declining over the course of several days to roughly constant concentrations from 1 to $2.5 \mu \mathrm{g} \mathrm{L}^{-1}$ over the remainder of the campaign. The profile of chlorophyll suggests a phytoplankton bloom peak and decay was sampled in the first period of the campaign which transitioned into a roughly constant moderately biologically productive state for the remainder of the campaign. $F_{D M S}: F_{M e S H}$ during the period of peak chlorophyll concentrations over the first three days of the campaign (DOY 245 - 247) was $10.8 \pm 4.4$ compared to the mean ratio from the full campaign of $5.5 \pm 3.0$. The relative production and consumption of DMS and MeSH in seawater is known to be a complex function of the speciation and abundance of phytoplankton and bacteria as well as available organic sulfur and other biogeochemical parameters (Kiene et al., 2000; Kiene and Linn, 2000b). No other measured meteorological parameters including wind speed, SST, and solar irradiance showed a significant correlation with $F_{D M S}: F_{M e S H}$. The underlying cause for the correlation between $F_{D M S}: F_{M e S H}$ and chlorophyll in our dataset is not clear without additional constraints on the ocean biochemistry. However, this result highlights that biological activity can drive variations in dissolved ratios of DMS and MeSH resulting in variability in ambient $F_{D M S}: F_{M e S H}$ emission ratios, and that further study is needed to elucidate this mechanism and its spatiotemporal variability. Measurements during an induced mesocosm phytoplankton bloom experiment using seawater collected as SIO pier immediately before this study showed that the ratio of gas phase DMS to MeSH varied by more than a factor of five over the course of a phytoplankton bloom and decay (Kilgour et al., 2021). DMS to MeSH ratios in that study were strongly linked to changes in bacterial sulfur demand and changes in the available pool of dissolved sulfur 
across the phytoplankton bloom and decay cycle. While induced mesocosm blooms are not fully representative of the ambient ocean, those results demonstrate the controlling role of ocean biology on $F_{D M S}$ and $F_{M e S H}$ and ultimately on marine $\mathrm{SO}_{2}$ production which must be better constrained through further ambient observations.
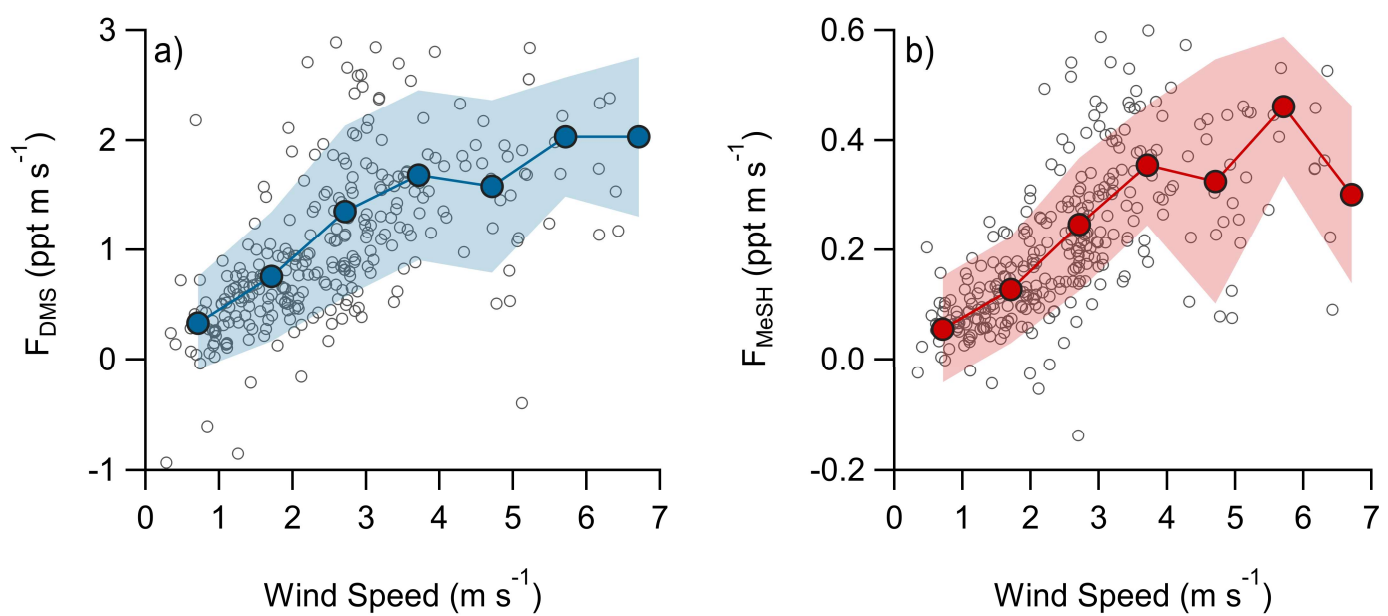

Figure 4. Flux of (a) DMS and (b) MeSH as a function of wind speed. Open circles are individual thirty-minute data points and closed circles are mean fluxes binned by wind speed at a $1 \mathrm{~m} \mathrm{~s}^{-1}$ bin spacing. Shaded regions are $\pm 1 \sigma$ of the binned mean.
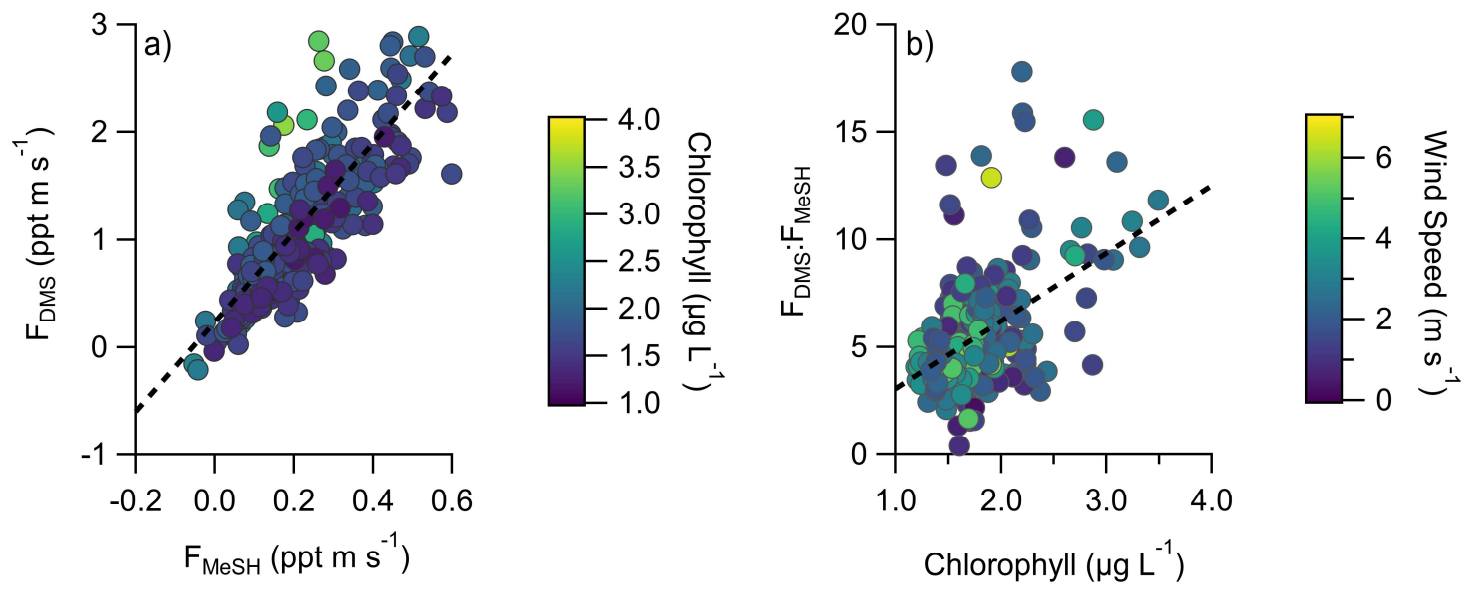

Figure 5. (a) Correlation and linear-least squares regressions of measured MeSH and DMS emission fluxes ( $F_{M e S H}$ and $F_{D M S}$ respectively). The slope of the best fit line is 4.15 and $R^{2}=0.65$. (b) Correlation and linear-least squares regression of the emission 
flux ratio of DMS to MeSH ( $\left.F_{D M S}: F_{M e S H}\right)$ with ocean chlorophyll concentrations. The slope of the best fit line is 3.15 and $\mathbf{R}^{2}=0.15$. Points in (a) are colored by ocean chlorophyll concentrations and in (b) by mean wind speeds for each flux period.

\section{3.4 Chemical Box Model Comparison to Pier Observations}

We assessed the ability of the coupled ocean-atmosphere chemical box model described in Section 2.4.2 using the Pier Model Case to replicate the observed mean diel profiles of DMS and MeSH mixing ratios from the SIO pier. The model and measurement diel profiles of DMS and MeSH are shown in Fig. 6. For MeSH the model agrees with measurements to within $25 \%$ during daytime hours $(10-21)$ when direct flux constraints were possible but diverges significantly at night where the model underpredicts MeSH. DMS is overpredicted by roughly 25 ppt during daytime (hours 9 to 20) in the model. Modeled DMS also shows less day-night variability in concentration, varying by a factor of 1.25 compared to observations which vary by approximately a factor of 2 . The poorer model performance at night is likely related to diel changes in coastal boundary layer dynamics, including boundary layer height and advection, which are not captured in the model. The model shows generally good performance during daytime when winds are consistently from the ocean and direct flux measurements are available as constraints for the model. One potential driver of model overprediction of DMS during daytime is the exclusion of $\mathrm{BrO}$ chemistry from the base model due to the lack of observational constraints of $\mathrm{BrO}$ at the study site. BrO has been suggested to be an important oxidant of DMS which peaks in concentration in the afternoon (Saiz-Lopez et al., 2006, 2008). A model sensitivity run using an afternoon peak BrO concentration $\left([\mathrm{BrO}]_{\max }\right)$ of 1 ppt was performed which brings modeled DMS to within $10 \mathrm{ppt}$ of the observations during daytime but degrades model to observation agreement at night. Daytime $\mathrm{MeSH}$ mixing ratios are reduced by less than $0.5 \mathrm{ppt}$ in the $1 \mathrm{ppt} \mathrm{BrO}$ sensitivity test, as MeSH oxidation is still dominated by $\mathrm{OH}$. Due to the general good model to measurement agreement for DMS and MeSH during daytime for the base case and the lack of observational constraint on $\mathrm{BrO}$ during our study, we elect to exclude $\mathrm{BrO}$ chemistry from the model base case used in subsequent calculations. Inclusion of BrO chemistry would have minimal impact on model MeSH as described, and would serve to reduce DMS lifetime, increase the yield of DMSO and MSA from DMS oxidation, and reduce the yield of $\mathrm{SO}_{2}$ from DMS oxidation. The demonstrated model ability to reproduce observed DMS and MeSH mixing ratios during daytime when we have robust constraints on the emission flux suggests that the DMS and MeSH oxidation mechanism added to the MCM v3.3.1 in this work is suitably accurate to provide meaningful information on the oxidative fate of DMS and MeSH. 

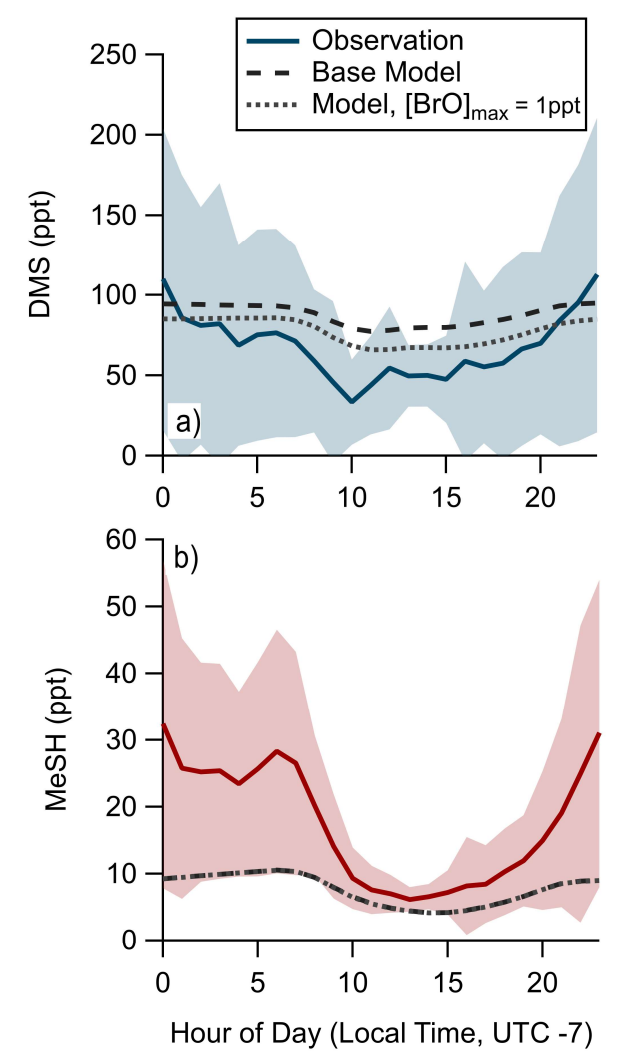

Figure 6. Observed and modeled diel profiles of (a) DMS and (b) MeSH mixing ratios.

\subsection{Impact of MeSH on Marine Sulfur Dioxide Production}

Production of $\mathrm{SO}_{2}$ as a function of $F_{D M S}$ and $F_{M e S H}$ was assessed using the Open Ocean case of the coupled ocean-atmosphere 0 -D box model described in Section 2.4.2.2. Chemical box modeling of MeSH emission and gas phase oxidation suggest that $\mathrm{MeSH}$ contributes significantly to marine boundary layer $\mathrm{SO}_{2}$ concentration. For a model case where $F_{M e S H}$ is taken to be 0 , and $F_{D M S}$ is taken to be the campaign mean of $1.1 \mathrm{ppt} \mathrm{m} \mathrm{s}{ }^{-1}$, modeled afternoon (hours 12 to 16 ) mean $\mathrm{SO}_{2}$ mixing ratio is 29.5

$395 \mathrm{ppt}$, and the instantaneous $\mathrm{SO}_{2}$ production rate $\left(P_{S O 2}\right)$ is $5.8 \mathrm{ppt} \mathrm{h}^{-1}$. When $F_{M e S H}$ is added to the model at the observed campaign

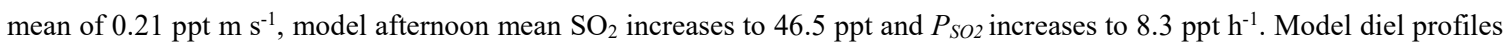
of $\mathrm{SO}_{2}$ mixing ratios and $\mathrm{P}_{\mathrm{SO} 2}$ with and without $\mathrm{MeSH}$ emissions are shown in Fig 7. In the campaign mean case MeSH emissions contribute $30 \%$ of the overall $\mathrm{SO}_{2}$ production (or a $43 \%$ increase in total $\mathrm{SO}_{2}$ production compared to the $F_{D M S}$ only case). The model yield of $\mathrm{SO}_{2}$ from MeSH oxidation was 0.99 which is comparable to an experimentally constrained model

400 determination of the atmospheric yield of 0.98 (Chen et al., 2021). We include the full MeSH oxidation mechanism for completeness due to its overlap with known DMS chemistry and ease of implementation in the box model. But given our 
determined model yield of $\mathrm{SO}_{2}$ from $\mathrm{MeSH}$ of 0.99 , and a recently determined yield of 0.98 constrained by laboratory oxidation studies (Chen et al., 2021), future modeling efforts may be justified in simplifying this mechanism by including only a direct $\mathrm{MeSH}+\mathrm{OH} \rightarrow \mathrm{SO}_{2}$ reaction at a yield of 1 . Prior efforts to constrain the total $\mathrm{SO}_{2}$ budget in the marine boundary layer required a unit yield of $\mathrm{SO}_{2}$ from DMS (Faloona et al., 2009) which stands in contrast to the $40-80 \%$ range typically determined in laboratory and modeling studies (Faloona, 2009; Gray et al., 2011). This discrepancy has prompted consideration that other potential $\mathrm{SO}_{2}$ precursors might be present which might reduce the yield of $\mathrm{SO}_{2}$ from $\mathrm{DMS}$ needed to close the $\mathrm{SO}_{2}$ budget (Bandy et al., 2011). Oceanic MeSH emissions as observed in our study are likely one such additional contributor to secondary marine $\mathrm{SO}_{2}$ which has not been previously considered. Eddy covariance flux measurements of ocean-atmosphere trace gas exchange have generally been limited to a small set of molecules (e.g. DMS, acetone, methanol, acetaldehyde) (Novak and Bertram, 2020). As demonstrated with the MeSH measurements presented here, marine EC flux observations of new molecules are critical to constrain marine sulfur and volatile organic compound (VOC) budgets. Global spatiotemporal variability of $\mathrm{MeSH}$ emission flux magnitude and the ratio of $F_{D M S}: F_{M e S H}$ are both highly uncertain due to the sparsity of ambient observations, which will need to be better constrained through future studies.

415 Heterogeneous chemistry of the DMS oxidation product HPMTF is not included in our base model case. HPMTF heterogeneous chemistry has been proposed to be a potentially large sink for HPMTF which would reduce $\mathrm{SO}_{2}$ production from DMS (Novak et al., 2021; Veres et al., 2020; Vermeuel et al., 2020). These details of HPMTF heterogeneous chemistry do not impact the yield of $\mathrm{SO}_{2}$ from MeSH described previously but do impact the calculated relative production of $\mathrm{SO}_{2}$ from MeSH compared to DMS. Inclusion of HPMTF heterogeneous chemistry (at $\gamma=0.01$ and aerosol surface area of $48 \mu \mathrm{m}^{2} \mathrm{~cm}^{-3}$ ) reduces model $\mathrm{SO}_{2}$ production from DMS to $2.7 \mathrm{ppt} \mathrm{h}^{-1}$ compared to $5.8 \mathrm{ppt} \mathrm{h}^{-1}$ in the model base case. In the HPMTF heterogeneous chemistry case MeSH oxidation accounts for $48 \%$ of marine $\mathrm{SO}_{2}$ production. Further details on HPMTF chemistry are given in SI S3.

We also note that the yield of $\mathrm{SO}_{2}$ production from $\mathrm{MeSH}$ does not have a temperature dependence, unlike DMS, which may result in MeSH being an especially important source of $\mathrm{SO}_{2}$ in colder high latitude regions. At lower temperatures, the DMS $\mathrm{OH}$-addition reaction pathway becomes more favored, resulting in less efficient production of $\mathrm{SO}_{2}$ from DMS oxidation as production of highly soluble intermediates begins to dominate compared to at higher temperatures. Model calculations presented here used the measured diel temperature profile at the SIO pier during this study which had a mean of $293 \mathrm{~K}$.

Modeled daytime $P_{\mathrm{SO}_{2}}$ as a function of DMS and MeSH emission flux magnitude are shown in Fig. 8 with the interquartile range of $F_{M e S H}$ and $F_{D M S}$ measured SIO pier emission fluxes overlaid as a constraint. These results highlight the potential variability in $P_{S O 2}$ in varying regimes of $F_{D M S}: F_{M e S H}$. Model results were from the base Open Ocean Case described in Section 2.4.2.2. Given the potential biological control on $F_{D M S}: F_{M e S H}$, the temperature dependence of $\mathrm{SO}_{2}$ yield from DMS, and the impact of HPMTF heterogeneous chemistry on $\mathrm{SO}_{2}$ yield from DMS, we expect there may be significant temporal and regional variability in the relative contribution of DMS and $\mathrm{MeSH}$ to marine $P_{\mathrm{SO}_{2}}$ across the global oceans. This additional $\mathrm{SO}_{2}$ production from MeSH will likely contribute to new particle formation and growth through enhanced production of sulfuric acid $\left(\mathrm{H}_{2} \mathrm{SO}_{4}\right)$ with subsequent impacts on $\mathrm{CCN}$ abundance in the MBL. Given the newly determined significance of both 
MeSH emissions and HPMTF heterogeneous chemistry on marine $\mathrm{SO}_{2}$ production, a critical reevaluation of the global marine $\mathrm{SO}_{2}$ budget is likely warranted.

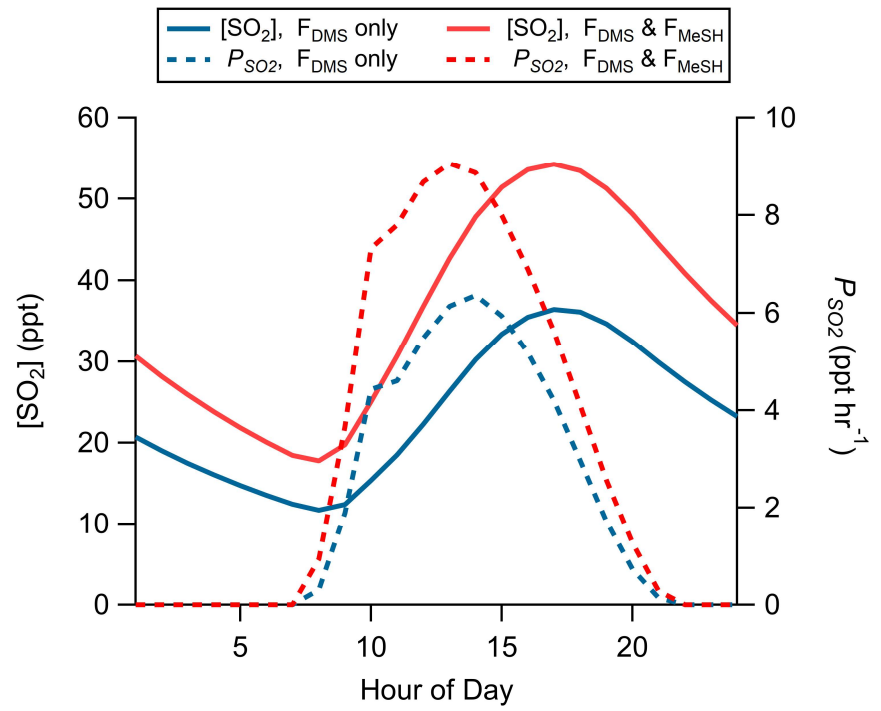

Figure 7. Modeled diel profiles of $\mathrm{SO}_{2}$ mixing ratios and instantaneous $\mathrm{SO}_{2}$ production rates $\left(\mathrm{P}_{\mathrm{So}}\right)$ for a model case considering only

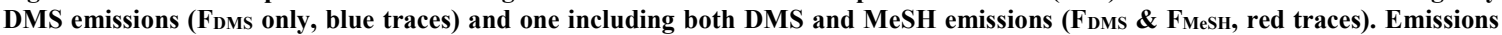
were taken as the measured campaign mean flux of DMS and MeSH.

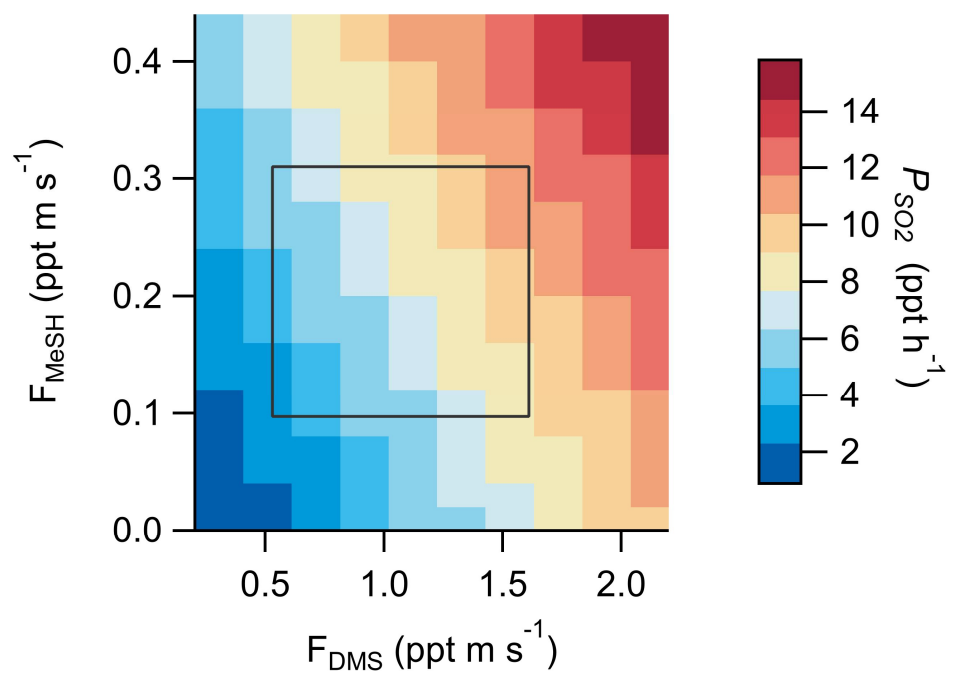

Figure 8. Modeled $\mathrm{SO}_{2}$ production rate $\left(\mathrm{PSO}_{2}\right)$ in the marine boundary layer as a function of MeSH and DMS emission fluxes. The interquartile range of measured $\boldsymbol{F}_{D M S}$ and $\boldsymbol{F}_{M e S H}$ at SIO pier is plotted as a black square. 


\section{3.6 Limited observational evidence for other volatile organic sulfur compounds}

In addition to DMS and MeSH, several other volatile organic sulfur compounds (VOSCs) have been reported to be significant in the marine atmosphere, either from direct oceanic emissions or gas phase oxidation of precursor species. Recent shipborne observations in the Arabian Sea reported high mixing ratios of dimethyl sulfone $\left(\mathrm{DMSO}_{2}, 40-120 \mathrm{ppt}\right)$ and methane sulfonamide (MSAM, 20-50 ppt) downwind of a biologically productive upwelling region (Edtbauer et al., 2020). Reported

450 DMS in the same region was from 100-300 ppt. The authors in that study propose a direct oceanic emission source of MSAM as there is no known gas phase oxidation pathway to produce MSAM from DMS. For our observations at Scripps Pier, both MSAM and $\mathrm{DMSO}_{2}$ were found to have no observable emission flux above the flux limit of detection at either the standard $3 \sigma$ LOD threshold or a more relaxed $1 \sigma$ LOD threshold. Gas phase mixing ratios of MSAM, DMSO, and $\mathrm{DMSO}_{2}$ were also not found to be significant, with none of those species consistently observed above the $10 \mathrm{~s}$ averaging time LOD of 2.4, 7.0,

455 and $9.2 \mathrm{ppt}$ respectively. All determinations of MSAM, DMSO, and $\mathrm{DMSO}_{2}$ mixing ratio and LOD assume they have the same detection sensitivity as DMS. Our measurements of $\mathrm{DMSO}$ and $\mathrm{DMSO}_{2}$ are consistent with box model calculated mixing ratios which show hourly maxima of $4.9 \mathrm{ppt}$ and $<0.1 \mathrm{ppt}$ for $\mathrm{DMSO}$ and $\mathrm{DMSO}_{2}$, respectively which are both below the instrument LOD. The box model conditions used were the Pier Model Case with the addition of [BrO $]_{\max }$ of 1 ppt. Oxidation of DMS by $\mathrm{BrO}$ favors DMSO and $\mathrm{DMSO}_{2}$ production and the inclusion of $[\mathrm{BrO}]_{\max }$ of 1 ppt was done as a test of the reasonable upper limit case for $\mathrm{DMSO}$ and $\mathrm{DMSO}_{2}$ production for conditions during this study. Dimethyl disulfide (DMDS, $\mathrm{CH}_{3} \mathrm{~S}_{2} \mathrm{CH}_{3}$ ) was also not consistently observed above the LOD in our measurements.

While a direct oceanic emission source of MSAM to the atmosphere has been proposed (Edtbauer et al., 2020), we did not measure a detectable MSAM emission flux in this study. As noted by Edtbauer et. al. (2020), given the Henry's law constant of $\operatorname{MSAM}\left(K_{H}=3.3 \times 10^{4} \mathrm{M} \mathrm{atm}^{-1}\right)$, the waterside concentration of MSAM necessary to drive a net emission flux of

465 MSAM to the atmosphere is on the order of $1700 \mathrm{nM}$. Given that maximum total dissolved organic sulfur (DOS) in ocean surface waters are on the order of $200 \mathrm{nM}$ (Ksionzek et al., 2016), even if all surface ocean DOS was in the form of MSAM, we still would not expect an emission flux of MSAM to the atmosphere. This exercise suggests MSAM may instead be formed through an unknown reaction pathway in the atmosphere which was active in the Arabian Sea but not in our observations at SIO Pier in coastal southern California. Taken together our observations indicate that MSAM, DMSO, and $\mathrm{DMSO}_{2} \mathrm{emission}$ fluxes and mixing ratios were small at the SIO Pier site consistent with model calculations.

This discussion on the lack of observations of other VOSCs only extends to molecules that are detectable with the Vocus PTR instrument, such as DMSO, $\mathrm{DMSO}_{2}, \mathrm{MSAM}$, and DMDS. For example, it does not include inorganic sulfur containing molecules such as carbonyl sulfide (OCS) and carbon disulfide $\left(\mathrm{CS}_{2}\right)$ which also have a known oceanic source but are not readily detectable by PTR. In particular our measurements do not include the recently observed DMS oxidation product HPMTF which was found to be a globally ubiquitous sulfur reservoir from airborne observations in the marine atmosphere (Veres et al., 2020) and in prior surface observations at the SIO Pier (Vermeuel et al., 2020). HPMTF is not detectable with the Vocus PTR ion chemistry used in this study. HPMTF was previously observed in the summer of 2018 at the SIO Pier site 
to have a strong diel profile, peaking in the early afternoon with an average daytime mixing ratio of 12.1 pptv (Vermeuel et al., 2020). While observations of HPMTF were made one year prior to the DMS and MeSH observations reported here, it suggests that HPMTF may comprise up to $10-20 \%$ of the total daytime VOSC concentration at this site during summer.

\section{Conclusions}

We present the first direct eddy covariance flux measurement of MeSH emissions from the ocean which show that MeSH emissions account for a mean of $16 \%\left(F_{M e S H} /\left(F_{M e S H}+F_{D M S}\right)\right)$ of emitted volatile organic sulfur measurable with the Vocus PTR-ToF during this study. DMS and MeSH emission fluxes were correlated with each other $\left(\mathrm{R}^{2}=0.65\right)$, consistent with their

485 shared oceanic source from the degradation of DMSP. Measured $F_{D M S}: F_{M e S H}$ was found to have a weak correlation $\left(\mathrm{R}^{2}=0.15\right)$ with chlorophyll concentrations, which highlights the need for further study of biogeochemical cycling in the ocean surface

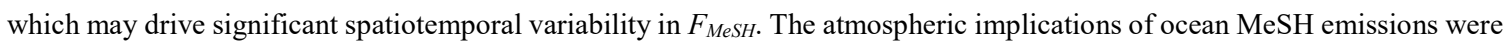
assessed by development of a MeSH oxidation mechanism and incorporation into a coupled ocean-atmosphere 0-dimensional chemical box model. Modeling results show that oxidation of MeSH by OH produces $\mathrm{SO}_{2}$ at a high yield ( 99\%) and is an important contributor to $\mathrm{SO}_{2}$ production in the marine atmosphere, driving an increase in afternoon $P_{\mathrm{SO} 2}$ of $2.5 \mathrm{ppt} \mathrm{hr}^{-1}$, corresponding to $30 \%$ of total afternoon $\mathrm{SO}_{2}$ production rates. In a model case including HPMTF heterogeneous uptake to aerosols, $\mathrm{SO}_{2}$ yield from DMS is reduced and MeSH becomes even more important, accounting for $48 \%$ of marine $\mathrm{SO}_{2}$ production. Taken together these results demonstrate that $\mathrm{MeSH}$ is an important contributor to volatile sulfur budgets in the marine atmosphere and that further studies are needed to constrain spatiotemporal trends of MeSH emission and oxidation relative to DMS.

Code and Data Availability. DMS and MeSH flux and concentration data and associated meteorological data from this study are archived at http://digital.library.wisc.edu/1793/82383.

Author Contributions. GAN, DBK, and THB designed research. GAN carried out the ambient sampling campaign and analyzed the data. MPV assisted with the ambient deployment. DBK conducted laboratory calibrations and developed

500 sampling methods. CMJ and MPV contributed to model development. THB supervised the project. GAN and THB wrote the paper. All authors reviewed and edited the paper.

Competing Interests. Timothy H. Bertram is a member of the editorial board of Atmospheric Chemistry and Physics. The authors have no other competing interests to declare.

Acknowledgments. This work was supported by National Science Foundation (NSF) Grant GEO AGS 1829667 and through 505 the National Science Foundation Center for Aerosol Impacts on Chemistry of the Environment (NSF-CAICE) under Grant CHE 1801971. 


\section{References}

Andreae, M. O.: Ocean-atmosphere interactions in the global biogeochemical sulfur cycle, Mar. Chem., 30(C), 1-29, doi:10.1016/0304-4203(90)90059-L, 1990.

510 Archer, C. L. and Jacobson, M. Z.: Evaluation of global wind power, J. Geophys. Res. D Atmos., 110(D12), D12110, doi:10.1029/2004JD005462, 2005.

Bandy, A., Faloona, I. C., Blomquist, B. W., Huebert, B. J., Clarke, A. D., Howell, S. G., Mauldin, R. L., Cantrell, C. A., Hudson, J. G., Heikes, B. G., Merrill, J. T., Wang, Y., O’Sullivan, D. W., Nadler, W. and Davis, D. D.: Pacific Atmospheric Sulfur Experiment (PASE): Dynamics and chemistry of the south Pacific tropical trade wind regime, J. Atmos. Chem., 68(1),

515 5-25, doi:10.1007/s10874-012-9215-8, 2011.

Barnes, I., Hjorth, J. and Mihalapoulos, N.: Dimethyl sulfide and dimethyl sulfoxide and their oxidation in the atmosphere, Chem. Rev., 106(3), 940-975, doi:10.1021/cr020529+, 2006.

Bates, T. S., Charlson, R. J. and Gammon, R. H.: Evidence for the climatic role of marine biogenic sulphur, Nature, 329(6137), 319-321, doi:10.1038/329319a0, 1987a.

520 Bates, T. S., Cline, J. D., Gammon, R. H. and Kelly-Hansen, S. R.: Regional and seasonal variations in the flux of oceanic dimethylsulfide to the atmosphere, J. Geophys. Res., 92(C3), 2930, doi:10.1029/JC092iC03p02930, 1987b.

Bates, T. S., Lamb, B. K., Guenther, A., Dignon, J. and Stoiber, R. E.: Sulfur emissions to the atmosphere from natural sourees, J. Atmos. Chem., 14(1-4), 315-337, doi:10.1007/BF00115242, 1992.

Berndt, T., Scholz, W., Mentler, B., Fischer, L., Hoffmann, E. H., Tilgner, A., Hyttinen, N., Prisle, N. L., Hansel, A. and

525 Herrmann, H.: Fast peroxy radical isomerization and $\mathrm{OH}$ recycling in the reaction of $\mathrm{OH}$ radicals with dimethyl sulfide, J. Phys. Chem. Lett., 6478-6483, doi:10.1021/acs.jpclett.9b02567, 2019.

Berndt, T., Chen, J., Møller, K. H., Hyttinen, N., Prisle, N. L., Tilgner, A., Hoffmann, E. H., Herrmann, H. and Kjaergaard, H. G.: SO 2 formation and peroxy radical isomerization in the atmospheric reaction of $\mathrm{OH}$ radicals with dimethyl disulfide , Chem. Commun., 4-7, doi:10.1039/d0cc05783e, 2020.

530 Berresheim, H.: Biogenic Sulfur Emissions from the Subantarctic and Antarctic Oceans, Journa Gecophysical Res., 92(D11), 13245-13262, doi:https://doi.org/10.1029/JD092iD11p13245, 1987.

Bertram, T. H., Kimmel, J. R., Crisp, T. A., Ryder, O. S., Yatavelli, R. L. N., Thornton, J. A., Cubison, M. J., Gonin, M. and Worsnop, D. R.: A field-deployable, chemical ionization time-of-flight mass spectrometer, Atmos. Meas. Tech., 4(7), 14711479, doi:10.5194/amt-4-1471-2011, 2011.

535 Butkovskaya, N. I. and Setser, D. W.: Product Branching Fractions and Kinetic Isotope Effects for the Reactions of OH and OD Radicals with CH3SH and CH3SD, J. Phys. Chem. A, 103(35), 6921-6929, doi:10.1021/jp9914828, 1999.

Butkovskaya, N. I. and Setser, D. W.: Reactions of OH and OD radicals with simple thiols and sulfides studied by infrared chemiluminescence of isotopic water products: Reaction $\mathrm{OH}+\mathrm{CH} 3 \mathrm{SH}$ revisited, Int. J. Chem. Kinet., 53(6), 702-715, doi:10.1002/kin.21475, 2021. 
540 Carpenter, L. J., Archer, S. D. and Beale, R.: Ocean-atmosphere trace gas exchange, Chem. Soc. Rev., 41(19), 6473-6506, doi:10.1039/c2cs35121h, 2012.

Carslaw, K. S., Lee, L. A., Reddington, C. L., Pringle, K. J., Rap, A., Forster, P. M., Mann, G. W., Spracklen, D. V., Woodhouse, M. T., Regayre, L. A. and Pierce, J. R.: Large contribution of natural aerosols to uncertainty in indirect forcing, Nature, 503(7474), 67-71, doi:10.1038/nature12674, 2013.

545 Charlson, R. J., Lovelock, J. E., Andreaei, M. O. and Warren, S. G.: Oceanic phytoplankton, atmospheric sulphur, cloud, Nature, 330, 1987, 1987.

Chen, J., Berndt, T., Møller, K. H., Lane, J. R. and Kjaergaard, H. G.: Atmospheric Fate of the CH 3 SOO Radical from the CH 3 S + O 2 Equilibrium, J. Phys. Chem. A, 125(40), 8933-8941, doi:10.1021/acs.jpca.1c06900, 2021.

Clarke, A. D., Varner, J. L., Eisele, F., Mauldin, R. L., Tanner, D. and Litchy, M.: Particle production in the remote marine

550 atmosphere: Cloud outflow and subsidence during ACE 1, J. Geophys. Res. Atmos., 103(D13), 16397-16409, doi:10.1029/97JD02987, 1998.

Conley, S. A., Faloona, I., Miller, G. H., Lenschow, D. H., Blomquist, B. and Bandy, A.: Closing the dimethyl sulfide budget in the tropical marine boundary layer during the Pacific Atmospheric Sulfur Experiment, Atmos. Chem. Phys., 9(22), 87458756, doi:10.5194/acp-9-8745-2009, 2009.

555 Edtbauer, A., Stönner, C., Pfannerstill, E. Y., Berasategui, M., Walter, D., Crowley, J. N., Lelieveld, J. and Williams, J.: A new marine biogenic emission: Methane sulfonamide (MSAM), dimethyl sulfide (DMS), and dimethyl sulfone (DMSO2) measured in air over the Arabian Sea, Atmos. Chem. Phys., 20(10), 6081-6094, doi:10.5194/acp-20-6081-2020, 2020.

Faloona, I.: Sulfur processing in the marine atmospheric boundary layer: A review and critical assessment of modeling uncertainties, Atmos. Environ., 43(18), 2841-2854, doi:10.1016/j.atmosenv.2009.02.043, 2009.

560 Faloona, I., Lenschow, D. H., Campos, T., Stevens, B., van Zanten, M., Blomquist, B., Thornton, D., Bandy, A. and Gerber, H.: Observations of Entrainment in Eastern Pacific Marine Stratocumulus Using Three Conserved Scalars, J. Atmos. Sci., 62(9), 3268-3285, doi:10.1175/JAS3541.1, 2005.

Faloona, I., Conley, S. A., Blomquist, B., Clarke, A. D., Kapustin, V., Howell, S., Lenschow, D. H. and Bandy, A. R.: Sulfur dioxide in the tropical marine boundary layer: Dry deposition and heterogeneous oxidation observed during the pacific

565 atmospheric sulfur experiment, J. Atmos. Chem., 63(1), 13-32, doi:10.1007/s10874-010-9155-0, 2009.

Foken, T. and Wichura, B.: Tools for quality assessment of surface-based flux measurements, Agric. For. Meteorol., 78(1-2), 83-105, doi:10.1016/0168-1923(95)02248-1, 1996.

Galí, M., Levasseur, M., Devred, E., Simó, R. and Babin, M.: Sea-surface dimethylsulfide (DMS) concentration from satellite data at global and regional scales, Biogeosciences, 15(11), 3497-3519, doi:10.5194/bg-15-3497-2018, 2018.

570 Gray, B. A., Wang, Y., Gu, D., Bandy, A., Mauldin, L., Clarke, A., Alexander, B. and Davis, D. D.: Sources, transport, and sinks of SO 2 over the equatorial Pacific during the Pacific Atmospheric Sulfur Experiment, J. Atmos. Chem., 68(1), 27-53, doi:10.1007/s10874-010-9177-7, 2011.

Hoffmann, E. H., Tilgner, A., Schrödner, R., Bräuer, P., Wolke, R. and Herrmann, H.: An advanced modeling study on the 
impacts and atmospheric implications of multiphase dimethyl sulfide chemistry, Proc. Natl. Acad. Sci., 113(42), 11776-11781, doi:10.1073/pnas.1606320113, 2016.

Huebert, B. J., Blomquist, B. W., Hare, J. E., Fairall, C. W., Johnson, J. E. and Bates, T. S.: Measurement of the sea-air DMS flux and transfer velocity using eddy correlation, Geophys. Res. Lett., 31(23), 1-4, doi:10.1029/2004GL021567, 2004.

Jenkin, M. E., Saunders, S. M. and Pilling, M. J.: The tropospheric degradation of volatile organic compounds: A protocol for mechanism development, Atmos. Environ., 31(1), 81-104, doi:10.1016/S1352-2310(96)00105-7, 1997.

580 Kettle, A. J. and Andreae, M. O.: Flux of dimethylsulfide from the oceans : A comparison of updated gave global oceanic Kw-e, J. Geophys. Res. Atmos., 105, 26793-26808, 2000.

Kettle, A. J., Rhee, T. S., Von Hobe, M., Poulton, A., Aiken, J. and Andreae, M. O.: Assessing the flux of different volatile sulfur gases from the ocean to the atmosphere, J. Geophys. Res. Atmos., 106(D11), 12193-12209, doi:10.1029/2000JD900630, 2001.

585 Kiene, R. P.: Production of methanethiol from dimethylsulfoniopropionate in marine surface waters, Mar. Chem., 54(1-2), 69-83, doi:10.1016/0304-4203(96)00006-0, 1996.

Kiene, R. P. and Linn, L. J.: Distribution and turnover of dissolved DMSP and its relationship with bacterial production and dimethylsulfide in the Gulf of Mexico, Limnol. Oceanogr., 45(4), 849-861, doi:10.4319/lo.2000.45.4.0849, 2000a.

Kiene, R. P. and Linn, L. J.: The fate of dissolved dimethylsulfoniopropionate (DMSP) in seawater: Tracer studies using 35SDMSP, Geochim. Cosmochim. Acta, 64(16), 2797-2810, doi:10.1016/S0016-7037(00)00399-9, 2000b.

Kiene, R. P., Linn, L. J. and Bruton, J. A.: New and important roles for DMSP in marine microbial communities, J. Sea Res., 43(3-4), 209-224, doi:10.1016/S1385-1101(00)00023-X, 2000.

Kilgour, D. B., Novak, G. A., Sauer, J. S., Moore, A. N., Dinasquet, J., Franklin, E. B., Mayer, K., Winter, M., Morris, C. K., Price, T., Malfatti, F., Crocker, D. R., Lee, C., Cappa, C. D., Allen, H., Prather, K. A. and Bertram, T. H.: Marine gas-phase sulfur emissions during an induced phytoplankton bloom, Atmos. Chem. Phys. Discuss, (August), 1-24, doi:https://doi.org/10.5194/acp-2021-615, 2021.

Kim, M. J., Farmer, D. K. and Bertram, T. H.: A controlling role for the air-sea interface in the chemical processing of reactive nitrogen in the coastal marine boundary layer, Proc. Natl. Acad. Sci. U. S. A., 111(11), 3943-3948, doi:10.1073/pnas.1318694111, 2014.

600 Kim, M. J., Novak, G. A., Zoerb, M. C., Yang, M., Blomquist, B. W., Huebert, B. J., Cappa, C. D. and Bertram, T. H.: AirSea exchange of biogenic volatile organic compounds and the impact on aerosol particle size distributions, Geophys. Res. Lett., 44(8), 3887-3896, doi:10.1002/2017GL072975, 2017.

Krechmer, J., Lopez-Hilfiker, F., Koss, A., Hutterli, M., Stoermer, C., Deming, B., Kimmel, J., Warneke, C., Holzinger, R., Jayne, J., Worsnop, D., Fuhrer, K., Gonin, M. and De Gouw, J.: Evaluation of a New Reagent-Ion Source and Focusing Ion-

605 Molecule Reactor for Use in Proton-Transfer-Reaction Mass Spectrometry, Anal. Chem., 90(20), 12011-12018, doi:10.1021/acs.analchem.8b02641, 2018.

Ksionzek, K. B., Lechtenfeld, O. J., McCallister, S. L., Schmitt-Kopplin, P., Geuer, J. K., Geibert, W. and Koch, B. P.: 
Dissolved organic sulfur in the ocean: Biogeochemistry of a petagram inventory, Science (80-. )., 354(6311), 456-459, doi:10.1126/science.aaf7796, 2016.

610 Lana, A., Bell, T. G., Simó, R., Vallina, S. M., Ballabrera-Poy, J., Kettle, A. J., Dachs, J., Bopp, L., Saltzman, E. S., Stefels, J., Johnson, J. E. and Liss, P. S.: An updated climatology of surface dimethlysulfide concentrations and emission fluxes in the global ocean, Global Biogeochem. Cycles, 25(1), 1-17, doi:10.1029/2010GB003850, 2011.

Lawson, S. J., Law, C. S., Harvey, M. J., Bell, T. G., Walker, C. F., De Bruyn, W. J. and Saltzman, E. S.: Methanethiol, dimethyl sulfide and acetone over biologically productive waters in the southwest Pacific Ocean, Atmos. Chem. Phys., 20(5),

615 3061-3078, doi:10.5194/acp-20-3061-2020, 2020.

Leck, C. and Rodhe, H.: Emissions of marine biogenic sulfur to the atmosphere of northern Europe, J. Atmos. Chem., 12(1), 63-86, doi:10.1007/BF00053934, 1991.

Lee, C. L. and Brimblecombe, P.: Anthropogenic contributions to global carbonyl sulfide, carbon disulfide and organosulfides fluxes, Earth-Science Rev., 160, 1-18, doi:10.1016/j.earscirev.2016.06.005, 2016.

620 Liss, P. S. and Slater, P. G.: Flux of gases across the Air-Sea interface, Nature, 247(5438), 181-184, doi:10.1038/247181a0, 1974.

Lucas, D. D.: Mechanistic studies of dimethylsulfide oxidation products using an observationally constrained model, J. Geophys. Res., 107(D14), 1-26, doi:10.1029/2001jd000843, 2002.

Mai, T. V. T., Nguyen, H. T. and Huynh, L. K.: Kinetics of hydrogen abstraction from CH3SH by OH radicals: An ab initio RRKM-based master equation study, Atmos. Environ., 242(April), 117833, doi:10.1016/j.atmosenv.2020.117833, 2020.

Marandino, C. A., De Bruyn, W. J., Miller, S. D. and Saltzman, E. S.: Eddy correlation measurement of the air/sea flux of dimethylsulfide over the North Pacific Ocean, J. Geophys. Res. Atmos., 112(3), 1-12, doi:10.1029/2006JD007293, 2007.

Mardyukov, A. and Schreiner, P. R.: Atmospherically Relevant Radicals Derived from the Oxidation of Dimethyl Sulfide, Acc. Chem. Res., 51(2), 475-483, doi:10.1021/acs.accounts.7b00536, 2018.

630 Mauder, M., Cuntz, M., Drüe, C., Graf, A., Rebmann, C., Schmid, H. P., Schmidt, M. and Steinbrecher, R.: A strategy for quality and uncertainty assessment of long-term eddy-covariance measurements, Agric. For. Meteorol., 169, 122-135, doi:10.1016/j.agrformet.2012.09.006, 2013.

Novak, G., Vermeuel, M. and Bertram, T.: Simultaneous Detection of Ozone and Nitrogen Dioxide by Oxygen Anion Chemical Ionization Mass Spectrometry: A Fast Time Response Sensor Suitable for Eddy Covariance Measurements, Atmos.

635 Meas. Tech., 13, 1887-1907, doi:10.5194/amt-13-1887-2020, 2020.

Novak, G. A. and Bertram, T. H.: Reactive VOC Production from Photochemical and Heterogeneous Reactions Occurring at the Air-Ocean Interface, Acc. Chem. Res., doi:10.1021/acs.accounts.0c00095, 2020.

Novak, G. A., Fite, C. H., Holmes, C. D., Veres, P. R., Neuman, J. A., Faloona, I., Thornton, J. A., Wolfe, G. M., Vermeuel, M. P., Jernigan, C. M., Peischl, J., Ryerson, T. B., Thompson, C. R., Bourgeois, I., Warneke, C., Gkatzelis, G. I., Coggon, M. 640 M., Sekimoto, K., Bui, T. P., Dean-Day, J., Diskin, G. S., DiGangi, J. P., Nowak, J. B., Moore, R. H., Wiggins, E. B., Winstead, E. L., Robinson, C., Thornhill, K. L., Sanchez, K. J., Hall, S. R., Ullmann, K., Dollner, M., Weinzierl, B., Blake, D. R. and 
Bertram, T. H.: Rapid cloud removal of dimethyl sulfide oxidation products limits SO 2 and cloud condensation nuclei production in the marine atmosphere, Proc. Natl. Acad. Sci., 118(42), e2110472118, doi:10.1073/pnas.2110472118, 2021.

Perraud, V., Meinardi, S., Blake, D. R. and Finlayson-Pitts, B. J.: Challenges associated with the sampling and analysis of 645 organosulfur compounds in air using real-time PTR-ToF-MS and offline GC-FID, Atmos. Meas. Tech., 9(3), 1325-1340, doi:10.5194/amt-9-1325-2016, 2016.

Porter, J. G., De Bruyn, W. and Saltzman, E. S.: Eddy flux measurements of sulfur dioxide deposition to the sea surface, Atmos. Chem. Phys., 18(20), 15291-15305, doi:10.5194/acp-18-15291-2018, 2018.

Quinn, P. K. and Bates, T. S.: The case against climate regulation via oceanic phytoplankton sulphur emissions, Nature, 650 480(7375), 51-56, doi:10.1038/nature10580, 2011.

Riedel, T. P., Wolfe, G. M., Danas, K. T., Gilman, J. B., Kuster, W. C., Bon, D. M., Vlasenko, A., Williams, E. J., Lerner, B. M., Veres, P. R., Roberts, J. M., Holloway, J. S., Lefer, B., Brown, S. S. and Thornton, J. A.: An mcm modeling study of nitryl chloride (CINO2) impacts on oxidation, ozone production and nitrogen oxide partitioning in polluted continental outflow, Atmos. Chem. Phys., 14(8), 3789-3800, doi:10.5194/acp-14-3789-2014, 2014.

655 Saiz-Lopez, A., Shillito, J. A., Coe, H. and Plane, J. M. C.: Measurements and modelling of I2, IO, OIO, BrO and NO3in the mid-latitude marine boundary layer, Atmos. Chem. Phys., 6(6), 1513-1528, doi:10.5194/acp-6-1513-2006, 2006.

Saiz-Lopez, A., Plane, J. M. C., Mahajan, A. S., Anderson, P. S., Bauguitte, S. J. B., Jones, A. E., Roscoe, H. K., Salmon, R. A., Bloss, W. J., Lee, J. D. and Heard, D. E.: On the vertical distribution of boundary layer halogens over coastal Antarctica: Implications for O3, HOx, NOxand the Hg lifetime, Atmos. Chem. Phys., 8(4), 887-900, doi:10.5194/acp-8-887-2008, 2008.

660 Saunders, S. M., Jenkin, M. E., Derwent, R. G. and Pilling, M. J.: Protocol for the development of the Master Chemical Mechanism, MCM v3 (Part A): Tropospheric degradation of non-aromatic volatile organic compounds, Atmos. Chem. Phys., 3(1), 161-180, doi:10.5194/acp-3-161-2003, 2003.

Schobesberger, S., Junninen, H., Bianchi, F., Lonn, G., Ehn, M., Lehtipalo, K., Dommen, J., Ehrhart, S., Ortega, I. K., Franchin, A., Nieminen, T., Riccobono, F., Hutterli, M., Duplissy, J., Almeida, J., Amorim, A., Breitenlechner, M., Downard, A. J.,

665 Dunne, E. M., Flagan, R. C., Kajos, M., Keskinen, H., Kirkby, J., Kupc, A., Kurten, A., Kurten, T., Laaksonen, A., Mathot, S., Onnela, A., Praplan, A. P., Rondo, L., Santos, F. D., Schallhart, S., Schnitzhofer, R., Sipila, M., Tome, A., Tsagkogeorgas, G., Vehkamaki, H., Wimmer, D., Baltensperger, U., Carslaw, K. S., Curtius, J., Hansel, A., Petaja, T., Kulmala, M., Donahue, N. M. and Worsnop, D. R.: Molecular understanding of atmospheric particle formation from sulfuric acid and large oxidized organic molecules, Proc Natl Acad Sci U S A, 110(43), 17223-17228, doi:10.1073/pnas.1306973110, 2013.

670 Sciare, J., Mihalopoulos, N. and Dentener, F. J.: Interannual variability of atmospheric dimethylsulfide in the southern Indian Ocean, J. Geophys. Res. Atmos., 105(D21), 26369-26377, doi:10.1029/2000JD900236, 2000.

Sipila, M., Berndt, T., Petaja, T., Brus, D., Vanhanen, J., Stratmann, F., Patokoski, J., Mauldin, R. L., Hyvärinen, A. P., Lihavainen, H. and Kulmala, M.: The role of sulfuric acid in atmospheric nucleation, Science (80-. )., 327(5970), 1243-1246, doi:10.1126/science.1180315, 2010.

675 Stull, R. B.: An Introduction to Boundary Layer Meteorology., 1988. 
Tyndall, G. S. and Ravishankara, A. R.: Kinetics of the reaction of the methylthio radical with ozone at 298 K, J. Phys. Chem., 93(12), 4707-4710, doi:10.1021/j100349a006, 1989.

Tyndall, G. S. and Ravishankara, A. R.: Atmospheric oxidation of reduced sulfur species, Int. J. Chem. Kinet., 23(6), 483527, doi:10.1002/kin.550230604, 1991.

680 Veres, P. R., Andrew Neuman, J., Bertram, T. H., Assaf, E., Wolfe, G. M., Williamson, C. J., Weinzierl, B., Tilmes, S., Thompson, C. R., Thames, A. B., Schroder, J. C., Saiz-Lopez, A., Rollins, A. W., Roberts, J. M., Price, D., Peischl, J., Nault, B. A., Møller, K. H., Miller, D. O., Meinardi, S., Li, Q., Lamarque, J.-F. F., Kupc, A., Kjaergaard, H. G., Kinnison, D., Jimenez, J. L., Jernigan, C. M., Hornbrook, R. S., Hills, A., Dollner, M., Day, D. A., Cuevas, C. A., Campuzano-Jost, P., Burkholder, J., Paul Bui, T., Brune, W. H., Brown, S. S., Brock, C. A., Bourgeois, I., Blake, D. R., Apel, E. C., Ryerson, T. B., Neuman,

685 J. A., Bertram, T. H., Assaf, E., Wolfe, G. M., Williamson, C. J., Weinzierl, B., Tilmes, S., Thompson, C. R., Thames, A. B., Schroder, J. C., Saiz-Lopez, A., Rollins, A. W., Roberts, J. M., Price, D., Peischl, J., Nault, B. A., Møller, K. H., Miller, D. O., Meinardi, S., Li, Q., Lamarque, J.-F. F., Kupc, A., Kjaergaard, H. G., Kinnison, D., Jimenez, J. L., Jernigan, C. M., Hornbrook, R. S., Hills, A., Dollner, M., Day, D. A., Cuevas, C. A., Campuzano-Jost, P., Burkholder, J., Bui, T. P., Brune, W. H., Brown, S. S., Brock, C. A., Bourgeois, I., Blake, D. R., Apel, E. C. and Ryerson, T. B.: Global airborne sampling reveals a previously

690 unobserved dimethyl sulfide oxidation mechanism in the marine atmosphere, Proc. Natl. Acad. Sci. U. S. A., 117(9), 45054510, doi:10.1073/pnas.1919344117, 2020.

Vermeuel, M. P., Novak, G. A., Jernigan, C. M. and Bertram, T. H.: Diel profile of hydroperoxymethyl thioformate: evidence for surface deposition and multiphase chemistry, Environ. Sci. Technol., 54(19), 12521-12529, doi:10.1021/acs.est.0c04323, 2020.

695 Wei, J., Tang, G., Zhu, X., Wang, L., Liu, Z., Cheng, M., Münkel, C., Li, X. and Wang, Y.: Thermal internal boundary layer and its effects on air pollutants during summer in a coastal city in North China, J. Environ. Sci. (China), 70, 37-44, doi:10.1016/j.jes.2017.11.006, 2018.

Wilczak, J. M., Oncley, S. P. and Stage, S. A.: Sonic anemometer tilt correction algorithms, Boundary-Layer Meteorol., 99(1), 127-150, doi:10.1023/a:1018966204465, 2001.

700 Williams, T. L., Adams, N. G. and Babcock, L. M.: Selected ion flow tube studies of H3O+(H2O)0,1 reactions with sulfides and thiols, Int. J. Mass Spectrom. Ion Process., 172(1-2), 149-159, doi:10.1016/s0168-1176(97)00081-5, 1998.

Wolfe, G. M., Marvin, M. R., Roberts, S. J., Travis, K. R. and Liao, J.: The framework for 0-D atmospheric modeling (F0AM) v3.1, Geosci. Model Dev., 9(9), 3309-3319, doi:10.5194/gmd-9-3309-2016, 2016.

Wright, D.: Oceanographic data collected from station Scripps Pier in the Coastal Waters of California by Southern California Coastal Ocean Observing System (SCCOOS) at Scripps Institution of Oceanography (SIO) and assembled by Southern California Coastal Ocean Obser, [online] Available from: https://accession.nodc.noaa.gov/0157035, 2016.

Wu, R., Wang, S. and Wang, L.: New mechanism for the atmospheric oxidation of dimethyl sulfide. The importance of intramolecular hydrogen shift in a CH3SCH2OO radical, J. Phys. Chem. A, 119(1), 112-117, doi:10.1021/jp511616j, 2015. Yoch, D. C.: Dimethylsulfoniopropionate: Its sources, role in the marine food web, and biological degradation to 
https://doi.org/10.5194/acp-2021-891

Preprint. Discussion started: 3 November 2021

(C) Author(s) 2021. CC BY 4.0 License.

(c) (i)

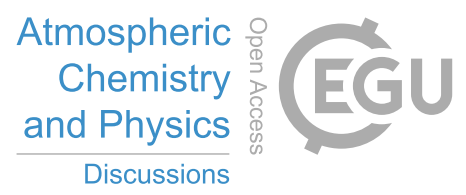

710 dimethylsulfide, Appl. Environ. Microbiol., 68(12), 5804-5815, doi:10.1128/AEM.68.12.5804-5815.2002, 2002. 